University of Louisville

ThinkIR: The University of Louisville's Institutional Repository

$5-2012$

\title{
"What do you mean I'm a slut?!?!" : deconstructing the definitions of promiscuity of the collective conscience using concepts from labeling theory and biopower.
}

Joshua O. Corum

University of Louisville

Follow this and additional works at: https://ir.library.louisville.edu/etd

\section{Recommended Citation}

Corum, Joshua 0., "'What do you mean I'm a slut?!?!" : deconstructing the definitions of promiscuity of the collective conscience using concepts from labeling theory and biopower." (2012). Electronic Theses and Dissertations. Paper 278.

https://doi.org/10.18297/etd/278

This Master's Thesis is brought to you for free and open access by ThinkIR: The University of Louisville's Institutional Repository. It has been accepted for inclusion in Electronic Theses and Dissertations by an authorized administrator of ThinkIR: The University of Louisville's Institutional Repository. This title appears here courtesy of the author, who has retained all other copyrights. For more information, please contact thinkir@louisville.edu. 


\title{
"WHAT DO YOU MEAN I'M A SLUT?!?!" \\ DECONSTRUCTING THE DEFINITIONS OF PROMISCUITY OF THE \\ COLLECTIVE CONSCIENCE USING CONCEPTS FROM LABELING THEORY AND BIOPOWER
}

\author{
by \\ Joshua O. Corum \\ B.A., Indiana University, 2007

\begin{abstract}
A Thesis
Submitted to the Faculty of the

College of Arts and Sciences at the University of Louisville

in Partial Fulfillment of the Requirements

for the Degree of
\end{abstract}

Master of Arts

Department of Sociology

University of Louisville

Louisville, Kentucky

May 2012 
Copyright 2012 by Joshua O. Corum

All rights reserved 


\title{
"WHAT DO YOU MEAN I'M A SLUT?!?!" \\ DECONSTRUCTING THE DEFINITIONS OF PROMISCUITY OF THE COLLECTIVE CONSCIENCE USING CONCEPTS FROM LABELING THEORY AND BIOPOWER
}

\author{
By \\ Joshua O. Corum \\ B.A., Indiana University, 2007 \\ A Thesis Approved on
}

April 20, 2012

by the following Thesis Committee:

Patricia Gagne, Ph.D, Thesis Director

Mark Austin, Ph.D.

Richard Tewksbury, Ph.D. 


\section{ACKNOWLEDGEMENTS}

No one is truly an island and no journey is made alone. Though I am very proud of this thesis and my accomplishment, I know achieving this goal was not possible without the help of many people. First, and foremost, I want to thank my advisor and Thesis Committee chair, Dr. Patricia Gagné, for her patience and support over the past two years. Pat strongly encouraged me to pursue my own research interests and was always willing to hash out ideas for this project. I would also like to thank my thesis committee members Dr. Mark Austin and Dr. Richard Tewksbury. Mark sacrificed many hours helping me conceptualize this thesis and talking me down from the proverbial academic ledge. I am grateful for his guidance and reassurance and consider him to be a mentor and a dear friend. I would also like to thank Dr. Richard Tewksbury for being flexible with his schedule, his thought-provoking questions, and his colorful language during my defense.

Many thanks to my friends and family, who may not know exactly why I'm still in school well into my 30's or why I study sex and sexuality, but are supportive nonetheless. I appreciate the many and sometimes uncomfortable conversations about their attitudes and views on sex and sexual behavior. Specifically, I want to thank my dear friend, the brilliant Amber Carrier, whose selflessness knows no bounds. From my graduate school application to the final edits of this thesis, she stood beside me each step 
of the way. None of this would have been possible without Amber's endless support and encouragement. I am grateful and honored to be her friend.

Finally, I want to extend a debt of gratitude to the management and staff at Panera Bread on Bardstown Rd. The majority of this thesis was written in Panera and their hospitality made those long hours much more bearable. 


\begin{abstract}
"WHAT DO YOU MEAN I'M A SLUT?!?!"

DECONSTRUCTING THE DEFINITIONS OF PROMISCUITY OF THE COLLECTIVE CONSCIENCE USING CONCEPTS FROM LABELING THEORY AND BIOPOWER

\author{
Joshua O. Corum \\ May 12, 2012
}

The term "promiscuity" is often used in academic literature and pejoratively proliferated among society at large. The definition of promiscuity has not been clearly and consistently defined within research and varies significantly from person to person. However, both research and society continue to utilize this term with the assumption of a universal meaning.

This study investigated how individuals construct their personal definition of promiscuity and how the subsequent label is applied to others. This thesis also examined how the definition of promiscuity is constructed within the collective conscience and how social institutions influence that definition. The relationship between the collective conscience and social institutions is analyzed using concepts from labeling theory and Foucault's biopower.

An extensive online survey was used to collect data from 210 respondents in the Louisville Metro area. The survey employed a quantitative and qualitative mixed methods approach, incorporating fixed answer and open-ended formatted questions. 
Five elements of promiscuity emerged from the qualitative analysis of the data: Number of Sexual Partners, Personal Connection, Time, Casual Attitude, and Unsafe Sex Practices. The quantitative analysis of these five elements indicated Relationship Status interacted with Casual Attitude; those not in a partnership were more likely to refer to casual attitudes on sex as an element of promiscuity. Two factors, Age and Sexual Double Standard Scale score, interacted with Unsafe Sex Practices. Younger respondents and those with lesser adherence to the sexual double standard were more likely to refer to unsafe sex practices in their definition of promiscuity.

Additional analyses were conducted to examine the interactions between the same factors and how an individual quantifies promiscuity in relationship to number of sexual partners. Respondents provided a numeric threshold for the promiscuity of a woman and a man. The analysis found three factors - Race, Sexuality, and Religiosity, affected the thresholds provided by respondents. Overall, the results of this study confirm the notion that promiscuity is a nebulous concept and provides support for challenging the use of this term in both future research and society alike. 


\section{TABLE OF CONTENTS}

PAGE

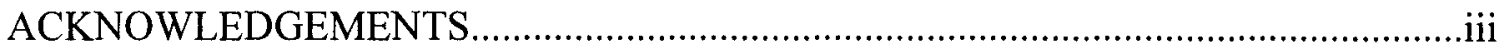

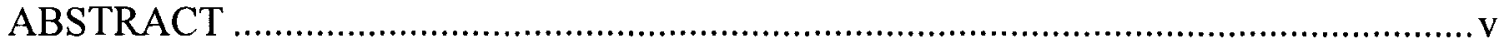

LIST OF TABLES

I. INTRODUCTION

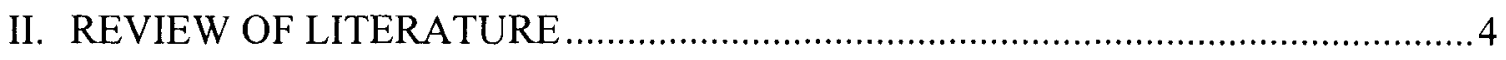

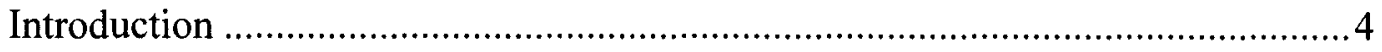

Promiscuity and Promiscuous ....................................................................

Multiple or A High Number of Sexual Partners................................................... 13

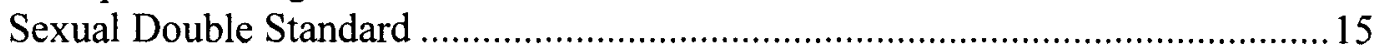

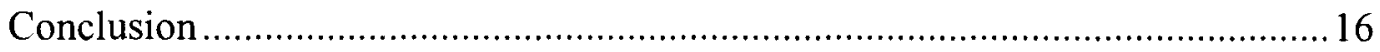

III. THEORETICAL CONSIDERATIONS …………................................................19

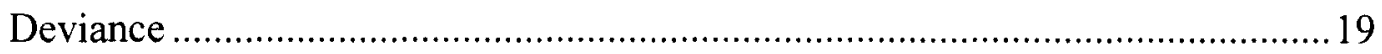

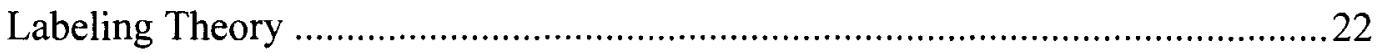

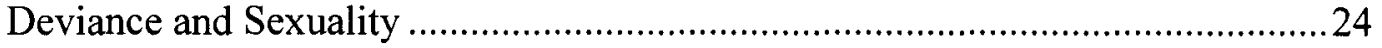

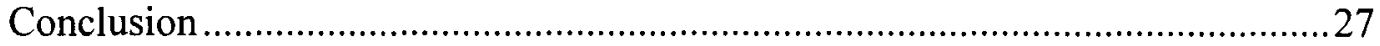

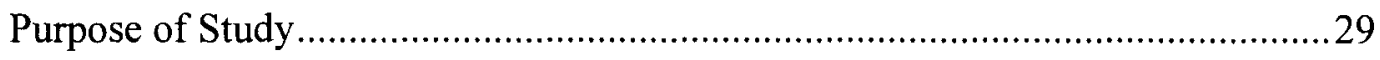

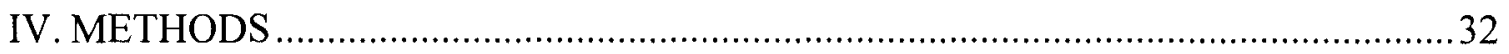

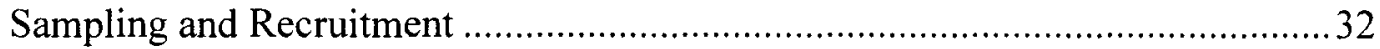

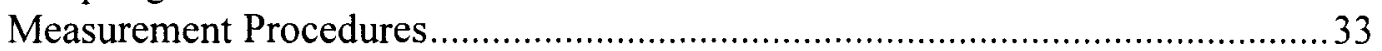

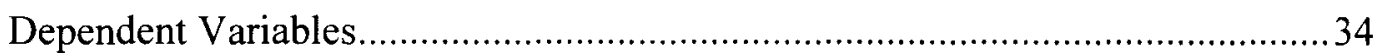

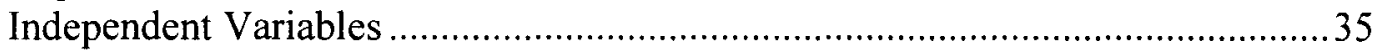

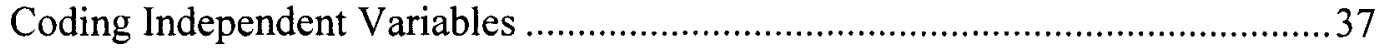

Quantitative Statistical Analyses ........................................................................ 


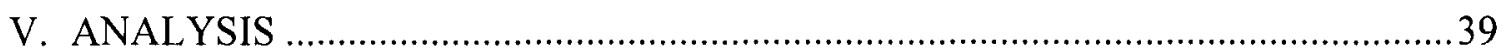

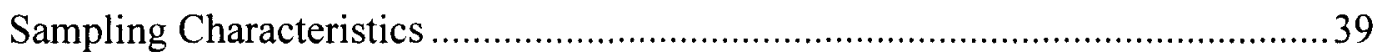

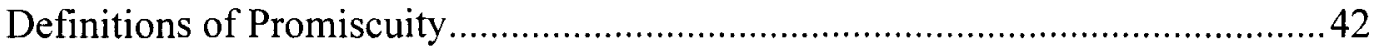

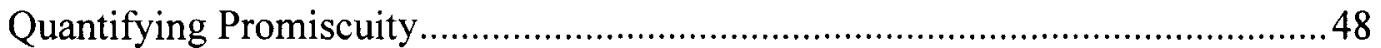

Promiscuity Threshold for a Woman..................................................50

Promiscuity Threshold for a Man .....................................................51

VI. DISCUSSION AND STUDY LIMITATIONS …................................................5

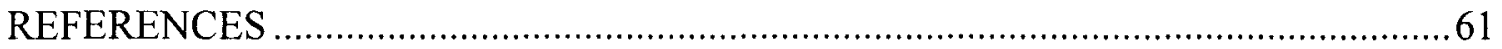

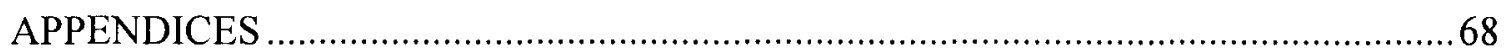

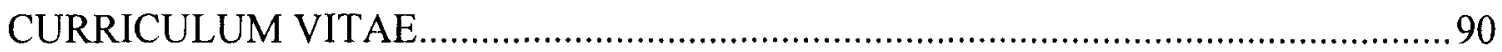




\section{LIST OF TABLES}

1. Table 1. Demographics: Study Sample vs. Louisville MSA ....................................41

2. Promiscuity Conceptual Memos by Frequency and Example ..................................43

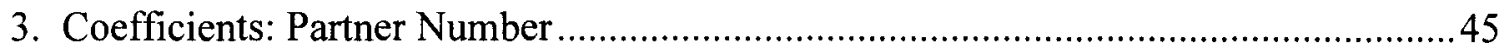

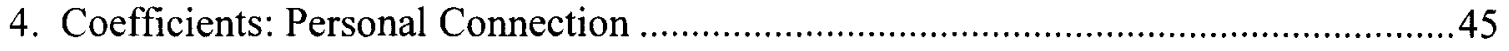

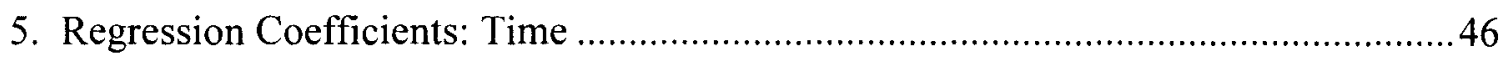

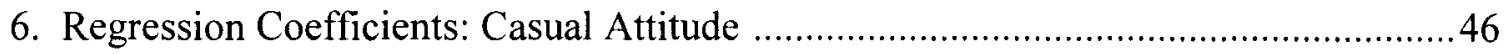

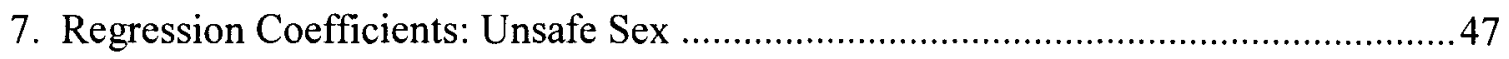

8. Promiscuity Thresholds by Age, Sex, Race, Education, Sexuality,

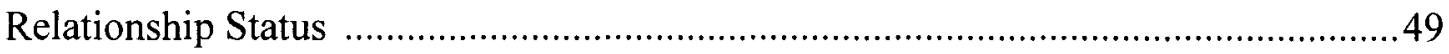

9. Regression Coefficients Promiscuity Threshold: Woman........................................ 51

10. Regression Coefficients Promiscuity Threshold: Man ............................................52 


\section{CHAPTER I}

\section{INTRODUCTION}

An essential first step in discerning the cultural from the human is what mythologist Joseph Campbell called detribalization. We have to recognize the various tribes we belong to and begin extricating ourselves from the unexamined assumptions each of them mistakes for the truth.

Christopher Ryan and Cacilda Jethá 2010: 22

If sex is repressed, that is, condemned to prohibition, nonexistence, and silence, then the mere fact that one is speaking about it has the appearance of a deliberate transgression. A person who holds forth in such language places himself to a certain extent outside the reach of power; he upsets established law; he somehow anticipates the coming freedom.

Michel Foucault, 1978: 6

"Whore," "slut," "stud," "easy," "pimp," "hooker," "man-whore," and "woman of ill-repute" are common pejorative slang terms used to refer to promiscuity or a person labeled as promiscuous. Definitions of labels are contextual to different cultures and societies and relative to historical specificity (Lemert 1972; Becker 1973). Previously, promiscuity or promiscuous simply meant "an indiscriminate mixture," the sexual connotation was not added until after 1865 (Harper 2012). In addition, slut and its counterpart stud, received their sexual implications roughly around the same time. Tramp moved from "vagabond or wanderer" to "promiscuous woman" in the 1920's and harlot and whore have been used interchangeably since the $14^{\text {th }}$ century (Harper 2012). 
Promiscuity is often deemed as immoral or deviant behavior; its commonly accepted meaning pertains to having several or multiple sexual partners and being indiscriminate in one's choice of sexual partners (Ellis 1968; Ryan and Jethá 2010). However, even this simple definition of promiscuity contains ambiguity and an abundance of room for individual interpretation. For example, one individual may view five sexual partners as "several" and morally inadmissible, whereas a different person would consider this to be a completely acceptable level of sexual exploration. The question then becomes is there a threshold for "several" or "multiple sexual partners" that constitutes promiscuity? What does it mean to be indiscriminate and after how many "indiscriminate partners" is a person to be labeled as promiscuous? By what or whose standards do we base the definition of promiscuity? The construction and definition of promiscuity, and subsequent labeling of individuals as such, is of particular interest in this study. This research seeks to uncover the social factors and institutional forces that influence how the label of promiscuity is constructed. In particular this study looks to answer the basic question: How do people personally define promiscuity?

The results of this project will add to the knowledge and understanding of how individuals come to formulate their views on acceptable sexual behavior and their own constructions of sexual deviance. This project also begins to fill a void in the research on promiscuity in academic literature. Though the concept of promiscuity is used frequently in academic literature, the term is often left vague and undefined or there are notable inconsistencies in the operationalization of promiscuity as a variable. Moreover, this study examines promiscuity as a constructed label, and given the dearth of literature on the topic may be among the first of its kind. In lieu of the limitations and discrepancies 
in academic research on promiscuity and the recent outcries over "slut-bashing," "slutshaming," and victim-blaming in the media, a scholarly examination of this topic is socially significant and timely. 


\section{CHAPTER II}

\section{REVIEW OF THE LITERATURE}

\section{Introduction}

The United States of America experienced the birth of overt sexual freedom during the "Roaring Twenties" (1920-1929) (Martin 1996). The writings of Marx, Nietzsche and the sexually charged Freud influenced a generation of young people to change the way they viewed sex and sexuality (Martin 1996). Young men and women ventured out together, attending "petting" parties and enjoying each other's company in the backseat of the newly popular automobile. However, during the same time, traditional gender and Victorian-era sex norms were still very strong and prevalent. The more dominant sexually conservative forces heavily contested the work of early sexual advocates such as Margaret Sanger, who pushed for women to take control of their reproduction through birth control (Martin 1996; D'Emilio and Freedman 1997).

However, the reality of hegemonic normative sexual behavior evaporated in the late 1940 s and early 1950 s when Alfred Kinsey released his (in)famous Kinsey Reports, which reported extensively on the sexual behavior of men and women (Kinsey, Pomeroy, and Martin 1948; Kinsey, Pomeroy, Martin, and Gebhard 1953; D’Emilio and Freedman 1997). Suddenly, there was, in a sense, a very sexual cat desperately searching for the bag from which it had just been abruptly ejected. The Kinsey Reports illustrated exactly how promiscuous the general public pretended not to be. Prior to that time 
period, sex was a very taboo subject that "respectable" members of society avoided for the sake of propriety. Sexual hegemony positioned morality at the forefront of acceptable behavior. The only socially acceptable sexual activities were between a man and a woman who were married to each other and were using sexual activity for procreative purposes only (Katz 1995; D’Emilio and Freedman 1997). All sex and sexual behavior contrary to that standard was considered by the general public to be immoral and deviant. Christian convention and morally subjective science led this crusade of sexual acceptability (Weeks 1985). In the late $19^{\text {th }}$ Century, medicine taught that sex more than once a month was unhealthy (Tannahill 1992: Katz 1995). Masturbation and sodomy were theorized by medical experts to have serious physical and mental consequences and in some states perpetrators of sodomy were legally punishable. Homosexuality was diagnosed as a mental illness and in most states also illegal (Anonymous 1949; Wheeler 1960; Foucault 1978). However, what Kinsey showed was that people were having sex, in its many forms and frequencies for more than just procreation (D'Emilio and Freedman 1997).

As American society moved into the Sexual Revolution of 1960's and 1970's attitudes on sexual behavior morphed into more open, liberal, and accepting of what was once deemed deviant and unlawful (Pope and Knudsen 1965; Ellis 1968; D'Emilio and Freedman 1997). Additionally, views on promiscuity changed as well. From the early 1960 s through the 1970s, attitudes towards promiscuity moved from 'sinful' to mildly immoral, in what appeared to be a decrease in the sexual double standard and an apparent balancing of sexual agency and freedom for men and women (Robinson, Robinson, Ziss, Ganza, and Katz 1991). Some of these changes were believed to be the result of 
advancements in and accessibility of medical technology (contraception and abortions) and progressively liberal political and social changes (Ellis 1968; Martin 1996).

The openness toward promiscuity and sexual behavior reduced considerably in the early 1980 s with the discovery and proliferation of HIV (Winkler 2005). Promiscuity, especially for men who have sex with men, became public enemy number one as a risk factor for the spread of infection (Shilts 1988; Diamond 1989). Early and inaccurate HIV research reshaped how society viewed promiscuity and homosexuality. Believed to be an exclusively "gay plague", a promiscuous lifestyle was often cited as the cause of HIV infection (Shilts 1988). This assumption persisted until children and prominent members of society had contracted HIV through birth or blood transfusions, respectively, illustrating that there were other mechanisms of virus transmission. Suddenly, infection was no longer isolated to a specific population, but the concern of everyone (Shilts 1988). From that point on, promiscuity or "multiple sexual partners" has been considered a risk factor for HIV and other sexually transmitted infections (Workowski and Berman 2010; Seem, Ingi, Umscheid, and Kuehnert, 2011).

The commonly held assumption that promiscuity is correlated to HIV infection is prevalent in a large portion of research on mental, physical, and public health (Wiley and Herschkorn 1988; Schmitt 2004; Antecol and Bedard 2007). Promiscuity is deemed an undesired characteristic or deviant behavior in criminology (Farrington 1998; Delavande, Goldman, and Sood 2010). Additionally, both uses of the term promiscuity as a risk factor and a deviant behavior are utilized in social science research (Spatz and Kuhns 1996; Meston, Heimen, and Trapnell 1999, Harris, Skilling, and Rice 2001; Anonymous 2002). It is important to note that in this review, the results of the research are not in 
question, but rather how promiscuity and its allusions are operationalized and defined. This study examines how promiscuity is defined, not the outcomes of its operationalization to other variables. The current issue in research, as it pertains to this study, is often the operationalized parameters or the conceptual definition of promiscuity is not presented. If the promiscuity variable is operationalized, the parameters or definitions do not concur or transpose with other research. Put more directly, researchers seem to tacitly assume that there is a commonly held definition for promiscuity among scientists and the public alike, despite the lack of research showing a common consensus on what promiscuous or "multiple" or a "high number" of sexual partners means.

There has been limited research on the societal definitions of promiscuity and how the subsequent label is constructed. Before examining how society defines promiscuity, it is important to examine how the information provided by institutions, considered to be experts and authorities, influence what is normative or acceptable social behavior. This review of the literature is to examine how 'promiscuity' (including its slang and allusions) is operationalized, used, or referred to in research. In this review, I will examine current research in two ways. First, I will examine the actual term 'promiscuity' and the different euphemisms as they are used in various fields of academic literature. Second, I will critique research that alludes to promiscuity as having a "high number of sexual partners" or "multiple sexual partners." Lastly, I will compare and contrast sources and identify patterns in the operationalization and definition of promiscuity and its allusions. 


\section{"Promiscuity or Promiscuous"}

Studies containing the words 'promiscuity' or 'promiscuous' are numerous and speculatively would be difficult to fully examine. In this analysis, an investigation of the research looks at the use of promiscuity as a variable or a component within the structure of source's theoretical argument. Additionally, the use of the terms is examined to identify how they are operationalized and defined.

As a variable, promiscuity is handled differently depending on the construction of the study. In one style of research, promiscuity is operationalized as a characteristic or trait to be rated on a scale by participants (Buss and Schmitt 1993; Schmitt 2004; Clayton and Trafimow 2007; La France, Henningsen, Oates and Shaw 2009). In some studies, the participants were presented with different targets and asked to rate the perceived level of promiscuity (Clayton and Trafimow 2007; La France et. al. 2009). Clayton and Trafimow (2007) asked participants to rate the level of sluttiness (promiscuity) of a hypothetical female target on a scale of 0 to 3 , with 3 being "extremely slutty." The presented hypothetical target was described as a female having six sexual partners in a month. The occupations of the six partners were either high status or low status. The purpose of the project was to examine how participants rated the targets' level of promiscuity based on the occupation level of the sex partners. The authors provided no justification for choice of a constant of 6 partners as the basis of the "promiscuous" target (Clayton and Trafimow 2007).

Conversely, a meta-analysis by La France et al. (2009) looked at other academic research to examine how men and women perceived the "promiscuousness," flirtatious, and seductive behavior of other male and female targets. As reported in La France et al., 
(2009) in one study participants rated how they perceived the targets in relationship to the three behaviors on a Lickert-scale of 1 to 7 . However, La France et al. did not make mention of how promiscuity or the other two concepts, flirtatiousness and seductiveness, were defined. The reader and possibly the participants were left to make that judgment based on their own individual definitions.

In other studies, participants rated their own behavior or the acceptability of promiscuity in a partner (Buss and Schmitt 1993; Schmitt 2004). In Schmitt (2004), participants rated themselves on a scale of 1 to 9 how 'loose' and 'promiscuous' each participant personally felt they were. From those two items, Schmitt (2004) constructed a subscale called 'Promiscuity' based on the participants' self-analysis. 'Infidelity' was presented as a separate variable; whereas promiscuity was loosely defined as "numerous sexual partners" and referred to as a risk factor for HIV infection. Buss and Schmitt (1993) reported the desirability of different characteristics in a potential long- and shortterm partner. According to their research, men seeking short-term relationships found promiscuity to be a 'mildly desirable' quality, whereas promiscuity was found to be 'undesirable' by men seeking a long-term relationship and women seeking both. However, Buss and Schmitt did not give a definition of promiscuity (1993). Another way promiscuity has been operationalized as a variable is through a researcher categorization of participants' self-reported behavior (Widom and Kuhns 1996; Wiley and Herschkorn 1998; Meston, et al. 1999; Victor 2004; Antecol and Bedard 2007; Markey and Markey 2007). Participants in these studies reported the types and frequencies of particular sexual behaviors. The guidelines for these behaviors and the frequencies at which they were deemed "promiscuous" were at the discretion of the 
researchers. Victor (2004) looked at how poor young teenage girls dealt with being labeled pejoratively -- for example being called a "slut." In this study, promiscuous sex was presented as "risky sexual behavior" and through qualitative methods the researchers determined that girls that reported "sex at an early age" and "many more sexual partners" were to be deemed as promiscuous. However, these researchers failed to suggest an actual age of sexual debut and how many partners constituted the threshold of "many more." Similarly, Antecol and Bedard (2007), used "promiscuity" in the title of their study, but did not reference either "promiscuity" or "promiscuous" in the text of the paper. Instead, they referred to teenage sex as "deviant" and, quite literally, "bad youth behavior." Although the researchers do not suggest why teenage sex (termed as promiscuity) is deviant or "bad," they did correlate teenage sex with marijuana and alcohol use as well as adolescent criminal behavior.

In other studies, the researchers based their classification of promiscuity on the reported frequencies of study participants on particular sexual behaviors (Widom and Kuhns 1996; Wiley and Herschkorn 1998; Meston et al. 1999; Markey and Markey 2007; IGN Entertainment 2011). One study simply used the reported number of lifetime sexual partners as their variable for promiscuity, suggesting that promiscuity began at 10 or more sexual partners (Widom and Kuhns 1996). The "Great Male Survey" (GMS) and "Great Female Survey" (GFS) conducted online through Askmen.com and Cosmopolitan.com respectively reported that women view the promiscuity of men and women similarly (IGN Entertainment 2011a; IGN Entertainment 2011b). The GFS reported thirty-eight percent of women said a man becomes a "man-whore" and thirtyseven percent said a woman becomes a "slut" after he or she has sex with their $20^{\text {th }}$ 
partner (IGN Entertainment 2011b). Conversely, in the GMS, 42\% of men said a woman is sexually promiscuous after she has sex with her $10^{\text {th }}$ partner. The GMS did not ask how men viewed other men (IGN Entertainment $2011 \mathrm{a}$ ). The questions asking about the promiscuity of men and women were in a fixed answer format. The fixed answers were predetermined number of sexual partners ranging from 5 to 100 and also a "Never" category (IGN Entertainment 2011a; IGN Entertainment 2011b). It can be assumed that the operationalization was referring to total number of lifetime partners, but no specification or justification for the number ranges was presented.

Other studies examined both number of partners and frequency of sexual activity (Wiley and Herschkorn 1988; Markey and Markey 2007). Though both studies suggested promiscuity was related to a higher number of partners, they also imply that the number of times engaging in different sexual activities is related to promiscuity. Wiley and Herschkorn (1988) studied the increased risk of HIV infection in relationship to the number of sexual partners and the number of times sexual activity occurred. Their research posits that promiscuity (alluded to as 100 sexual acts with two partners or a total of ten partners) put the individual at an elevated risk of infection. The correlation of 100 sexual incidents per number of partners to risky sexual behavior was based on the control factor that infection rates increase from 1 in 1000 to 1 in 100 . The operationalization in Markey and Markey (2007) follows a similar trajectory. Promiscuity is calculated by the number of partners with which respondents reported engaging in four sexual activities; "Kissing for 1 minute," "manual genital contact," "oral genital contact," and "sexual intercourse." In this study, promiscuity is defined as number of partners times the four sexual activities. However, the article did not present a scale, ratio, or threshold for how 
many partners per activity or combined activities constituted promiscuity. It could be assumed the researchers suggested that as number of partners increase per activity, the level of promiscuity increases, but no explicit statement of the sort was provided. For Meston et al. (1999), promiscuity was defined as "having more than one sexual partner at the same time" (387). However, in their study promiscuity was alluded to with the variable "unrestricted sexual behavior" which was scored based participants' self-reports of various behaviors such as number of lifetimes sexual partners, one-night stands, and willingness to participate in extensive foreplay, and cheating behavior.

"Promiscuity" or "promiscuous" are also used in some studies as concepts in theoretical arguments. In many of these studies, promiscuity is presented as a symptomatic behavior of violent criminal behavior or co-occurring with mental illnesses such as psychopathy, sexual addiction, or mania (Farrington 1998; Harris, Skilling, and Rice 2001; Kafka 2001; Benatar 2002; NCSAC 2002; Smith and Hattery 2006; Delavande, Goldman, and Sood 2010). Benatar (2002) attempted to build the argument that condoning or accepting promiscuity logically opens the door to accepting pedophilia and rape. In this case, promiscuity is defined as casual and unemotional sex without the need for romantic attachment, but there was no reference to how many casual or unemotional sexual partners constitutes being promiscuous. Farrington (1998) reported a correlation between promiscuity and violent criminal behavior in young men. However, the author does not provide a definition of promiscuity or how it was operationalized in the study. Additionally, the age of the first sexual experience of the young men was offered as a separate variable (Farrington, 1998). 
Other studies present promiscuity as a symptom of mental illness, such as psychopathy, hypersexuality, and sex addiction (Harris et. al. 2001; Kafka 2001; NCSAC 2002). In these examples, promiscuity was not defined and left to the reader to interpret. Harris et al. (2001) explains that sexual promiscuity can be measured "reliably and validly" with psychopathy, in that promiscuity is an aspect of psychopathy. The researcher does not suggest how to measure it, but does, however, differentiate between promiscuity and uncommitted sexual behavior. Delvanade et al. (2010) argue that increasing the level of prosecution of HIV+ individuals who purposely fail to protect their partner from infection may lead to HIV+ individuals to seek out promiscuous partners. Initially, the report referred to promiscuity simply as risky sexual behavior, but later it was operationalized as "sex with prostitutes." By the end of the report, Delvanade et al. (2010) changes the definition to "non-exclusivity," which made three distinct definitions of promiscuity within one study.

\section{"Multiple or A High Number of Sexual Partners"}

The studies presented above demonstrate how the terms promiscuity, promiscuous and similar euphemisms have been used and defined in academic literature. According to these studies, an element of promiscuity is engagement in sexual behavior with many or multiple sexual partners. I will next examine the use of the allusions to promiscuity and how they are operationalized and defined.

Most of the literature on "multiple" or a "high number" of sexual partners conflate promiscuity with high risk sexual behavior (Molina and Duarte 2006; Vignetta and Blum 2008; Bingenheimer and Geronimus 2009; Chandra, Billioux, Copen, and Sionean 2012). Some studies presented sex with "multiple" or "a high number" of sexual 
partners as a risk factor for HIV infection and other sexually transmitted diseases (Catania, Binson, Dolcini, Choi, Pollack, Hudes, Canshola, Phillips, Moskowitz, and Coates 1995; Vignetta and Blum 2008; Chandra et. al. 2012). Other studies make specific claims about the threshold to multiple or a high number of sexual partners (Garcia, 2006, Chandra et. al., 2012). In a National Health Statistics Report, Chandra et al. (2012) reported "five or more sexual partners in a year" as an HIV related measure, which was borrowed from another study that found an increased risk of HIV infection for those who had 5 or more partners in a year. Garcia (2006) asserted that based on pretest data, a high number of sexual partners is nine. The authors do not supply the pretest data or clearly explain how they derived the number nine.

While the above studies focus on number of lifetime sexual partners, some researchers believe risky sexual behavior, a.k.a. promiscuity, is relative to partner concurrency. These studies claim that having multiple active partners at the same time is a risk factor (Desiderato and Crawford 1995; Bingenheimer and Geronimus 2009). Conversely, unlike the studies that offer a numeric threshold to promiscuity, Desiderato and Crawford (1995) remain silent on how many concurrent partners represent promiscuity.

Finally, governmental bodies like The Center for Disease Control and Prevention (CDC\&P) and Public Health Services (PHS) allude to promiscuity by suggesting 'multiple sexual partners' and specific partner number thresholds as risk factors for STIs and HIV infection. A September 2011 publication from the CDC\&P and the PHS reported the evaluation of new protocols and guidelines for organ transplant donations. The new protocol is designed to decrease the chance of the organ recipient contracting 
HIV or other infections. The report presented a new rule that if a donor reportedly had two or more sexual partners within the past year, they would be considered a 'high-risk' organ donor. The report referred only to "low equality evidence" as the support and justification for the "high-risk" classification. Additionally, the same report stated "multiple sexual partners" are considered a risk factor for contracting other STIs such as HIV. The justification for this change was based on "different" or "undefined"

thresholds (Seem et al. 2011). Several of these reports do mention other risk factors and methods of prevention, such as use or lack of contraception and engaging in sexual behavior with an infected partner, but the ambiguity and inconsistency relating to the number of sexual partners is relative aspect to this study.

\section{Sexual Double Standard}

When examining definitions of promiscuity there is significant evidence that there are different societal expectations and allowances for men and women. The traditional idea of the "sexual double standard" holds that men have greater sexual freedom than women. Reiss (1956) described the sexual double standard as the idea that men have the freedom to engage in premarital sex, while women are prohibited from doing the same. A man who has had many sexual partners might be called a "stud" or be revered as being "successful" with little to no sigma. Conversely, a woman with comparable experiences may be called a "slut" or "easy" and face more severe social consequences (Barash and Lipton, 2001; Marks and Fraley, 2005).

Little information is available addressing the origins of the sexual double standard, but there is an abundance of research pertaining to social beliefs and institutions that influence and sustain this double standard, such as sanctity of female chastity and 
messages from religion and family (Thomas 1959; DeLamater 1981). Although there is evidence that supports the belief that the sexual double standard is decreasing, suggesting a balancing of sexual agency (Marks and Farley 2005), there is just as many, if not more, experts in the field of human sexuality who claim the sexual double standard is still very prevalent in American society (Crawford and Popp 2003; Marks and Farley 2006;

Kreager and Staff 2009).

\section{Conclusion}

This literature review illustrates the discrepancies and similarities in the operationalization and definition of promiscuity either as a study variable, as component of the researchers' theoretical arguments, or as public health policy. However, the individual researchers often fail to operationalize and define promiscuity. If an operationalization or definition is offered, there is little to no agreement among the literature. When considering how to operationalize and define promiscuity, researchers look to a variety of different variables, such as age of sexual debut, the number of lifetime and concurrent sexual partners, and the frequency in which people engage in particular sexual activities. Researchers refer to the concept of promiscuity as it relates to mental illness and co-occurring deviant behavior, and a risk factor of STIs and HIV infection.

Nevertheless, it is disconcerting that there is a lack of consistency and agreement among researchers and their research on the definition of promiscuity or promiscuous sexual behavior. There are some studies that state promiscuity is based on number of sexual partners in a lifetime (Widom and Kuhns, 1996), while other sources suggest promiscuity is more complex and associated with the number of partners per designated 
sexual activity, age of sexual debut, or number of concurrent sexual partners (Wiley and Herschkorn 1988; Meston et. al. 1999; Victor 2004; Markey and Markey 2007). Some studies present scales for participants to rate their own level of promiscuity or that of others (Buss and Schmitt 1993; Schmitt 2004; La France et. al. 2009) just as others presented and gauged promiscuity by the often arbitrary standards of the researcher (Desiderato and Crawford 1995; Garcia 2006; Clayton and Trafimow 2007; Bingenheimer and Geronimus 2009; Chandra et. al. 2012).

There is even ambiguity and inconsistency within the research of governmental bodies that directly influence U.S. policy. The CDC\&P report that multiple or a high number of sexual partners are a risk factor for STI and HIV infection and recommends "reducing" or "limiting your number of sexual partners" as a preventative measure to decrease the likelihood of STI and HIV acquisition (Workowski and Berman 2010; Chandra et. al. 2012). While these reports allude to the definition of "multiple" as five or more sexual partners, they do not suggest a number by which a person should reduce their number of sexual partners. The report provides a brief medical rationale for why five is the threshold and but does not account for the risk gained between having four lifetime sexual partners and five or more (Chandra et al.2012). Oddly enough, the CDC\&P reports that the average male has approximately six sexual partners in his lifetime and females have roughly four (Chandra, Mosher, and Copen 2011). These averages increase for African Americans and Hispanic/Latinos (Santelli, Brener, Lowry, Bhatt and Zabin 1998; Rowe 2002). One can conclude that an average male is always at high risk for STIs and HIV and the average female is not far behind. In the report on organ donation protocol, the CDC\&P suggests, based what they call "low equality 
evidence," that after more than two sexual partners per year a person is essentially promiscuous and their body is unhealthy (Seem et al. 2011). Essentially, the CDC\&P does not take into account the sexual history of the partners one has. From this, one can assert that having two sexual partners per year that are virgins is the same risk level as having sexual intercourse with two partners that have ten a piece. From these reports, it can be surmised that the CDC\&P suggests reducing number of sexual partners to one per year, a number that is reminiscent of the themes of morally conservative sexual attitude.

While the literature has illustrated discrepancies in the definition of promiscuity among different researchers and institutions, the social consequences plague individuals labeled promiscuous, whether at the level of two partners per year, five or more over a lifetime, or another number. However, in Chapter 3 I will show that though these numbers are presumed to reflect societal standards, they are also influenced by the expertise and authority of social institutions. The issue of labeling a person as promiscuous and the subsequent social consequences are exacerbated by the ambiguous messages used by those social institutions. . 


\section{CHAPTER III}

\section{THEORETICAL CONSIDERATIONS}

This study utilizes concepts and theories on deviance and crime to demonstrate how societies collectively develop their community standards and definitions of deviance. These concepts and theories also explain how institutions such as science, medicine, and religion work to influence those standards and definitions. This theoretical framework lends support for the argument that the failure of scientific and medical research to define and operationalize promiscuity not only is bad science but that those imprecise messages from positions of authority and expertise are influential in shaping the social construction of promiscuity.

\section{Deviance}

According to Durkheim, crime is inevitable in society (1895). The socially established definition of crime seeks to demarcate behaviors and practices that a society deems morally unacceptable and thus punishable. The term "deviance" can be used in place of crime with the acknowledgement that not all deviance is criminal. Crime is determined and labeled by the culmination of the commonly held beliefs and values of society, or collective conscience (Durkheim 1895). A behavior is deemed criminal or deviant under the simple principle that "an act is socially bad because society disproves of it" (Durkheim 1893). Becker expands this idea by suggesting that "social groups create

deviance by making the rules whose infraction constitute deviance" (1973:9). Therefore, 
by engaging in disproven acts and breaking the established rules of society, a person is consequentially labeled as a deviant. Furthermore, the more a society can be considered homogenous the more definitive the collective conscience. This collective conscience is the result of a greater social solidarity and consensus of rules on acceptable behavior, which Durkheim referred to as mechanical solidarity (1893). The boundaries of acceptable behavior and deviance become more rigidly defined with an increasingly cohesive collective conscience. Thus, as homogeneity within a society increases, what the society considers deviant becomes more rigidly defined. Conversely, greater individuation in heterogeneity leads to a weaker collective conscience and less solidarity; the boundaries between normative and deviant are no longer as apparent (Durkheim 1893).

Arguably, our current society is far from homogenous and lacks a cohesive collective conscience. However, Durkheim argues that through an increased division of labor, heterogeneous societies develop their collectivity. By separating the roles and responsibilities in society, the pieces amalgamate to form an inner-working where the different parts form an intricate system that works to achieve similar goals. Communal interdependence and the similar goals become the foundation for the collective conscience of the heterogeneous society, or organic solidarity (Durkheim 1893). Though in diverse societies there is an increase in solidarity through increased division labor, it can be argued that the boundaries of acceptable behavior and deviance remain blurred.

In both mechanical and organic societies, Durkheim posited that the collective conscience emerged from consensus in the functionality of society, either from the similar world and moral view of the homogeneous collective or the shared goals and 
interdependence of heterogeneous collective (1893). In both cases, Durkheim's

"deviance" is a violation or offense against the established collective conscience.

However, issues of deviance and crime are resolved differently within the two societal

constructs. In a homogenous society, where moral boundaries are more distinct and the

people share a similar world view, violations of established rules and moral boundaries

are met with retributive law -- meaning punishments are often quick, harsh, and meant to

restore order to the collective conscience. The more diverse world view of a

heterogeneous society implements restitutive law in order to provide justice for the victim

rather than maintaining the strong communal solidarity (Durkheim 1893).

Durkheim's works on the collective conscience set the groundwork for examining how society, through consensus, establishes the boundaries of acceptable behavior and deviance. However, Durkheim failed to address the role of power in defining deviance. Durkheim referred to social facts, like norms and values, of a society that influence how people think, feel, and act. Like the conjectured invisible hand of the market that guides today's economy, Durkheim posited that social facts do not reside within the individual, but rather are outside him or her. These facts have the "power of coercion" to influence or control the individual (Durkheim 1895). Norms and values are established through the consensus of the collective and systems of law are a reflection of those norms and values. A critical element of the division of labor is that certain individuals are given the power to create and enforce these laws while others have less influence, a point that Durkheim overlooks. Our society places the responsibility of defining crime in the hands of lawmakers and the police while the definitions of deviance and morality emerge from institutions of authority or expertise such as the church, science, and medicine. Durkheim 
tacitly assumes the collective conscience emerges from the consensus among society, but neglects to address how those in established positions of power and authority frequently utilize power and coercion to push the subjective moral agenda of a select few as the foundation of the collective conscience rather than a unifying system of values.

Additionally, when actions and behaviors occur that visibly challenge the values of those in power; "the problem becomes one of social control, one solution is to define a person or persons categorically as deviant" (Lemert 1972:23).

\section{Labeling Theory}

The works of Becker, Lemert, Kistuse, and other theorists from the early to mid1900s heavily influence labeling theory (Becker 1973). It is arguably built from Goffman's work on stigma and Durkheim's work on social morality (Becker 1973; Goode 2001; McCaghy, Capron, and Jamieson 2003). The originators of this theory were reluctant to call it labeling theory because they felt the concepts presented did not fully constitute a theory (Becker 1973). The early theorists instead used this perspective as an approach to research social phenomena, especially deviance. They posit that labeling theory does not offer solutions or justifiable causation, but instead a means for a more inclusive examination and a more comprehensive inquiry of the social phenomena and influences. The basic tenets of labeling theory suggest that social interactions and reactions to particular behaviors contribute to how the label of deviance is constructed and applied to the behavior in question. "Deviance is not a quality that lies in behavior itself, but in the interactions between the person who commits an act and those who respond to it" (Becker 1973: p14). In addition, labeling theory stresses investigations of 
the different social and institutional forces that might influence the construction of that label.

Under the perspective of labeling theory, the examination of deviance or deviant behavior requires more exhaustive measures than simply applying the ambiguity of social morality. Labeling theory, like all sociological inquiry, encourages the rejection of hegemonic convention and cautions sociological researchers to not be blinded by common-sense assumptions about the behavior in question. Becker says, "A full understanding requires the thorough study of those definitions and the process by which they develop and attain legitimacy and taken-for-grantedness" (1973:207). If research does not argue against traditional or commonly held beliefs, then the results of that research will biased to the assumed values of convention and will fail to achieve an objective understanding of deviance (Lemert 1972; Becker 1973).

Under the same notion of objectivity, it is necessary for social specificity to examine the label of deviance within a specific social context. Defining deviance within a complete milieu of society would be very daunting and for most behaviors is relatively impossible, particularly since the definition of deviance ranges vastly between and even within social groups and individuals. However, by studying deviance within a specified social context -- for example juvenile delinquency among minorities in a particular neighborhood -- the researcher cannot only concisely identify the social, cultural, psychological, and institutional forces that define primary deviance, but also investigate the effects of how the labeled individuals feel about and react to the being labeled (Lemert 1972). 
When investigating primary deviance, Lemert suggested analyzing the concept of social control within the definition of the label of deviance. He proposed that we question how social entrepreneurs and institutional forces might classify deviant behavior as a means of social control (Lemert 1972; Becker 1973). Throughout history, sexual behavior has exemplified this process. Moral entrepreneurs, like the church, believe they are endowed with the knowledge of what is acceptable and unacceptable sexual behavior. Often these moral crusaders seek to influence science and medicine to categorize immoral or unacceptable sexual behaviors as "deviant" as means to control sex and sexuality. They often contort theories and evidence that support a specific moral agenda (Weeks, 1985). For example, the Christian view that a woman's place is in the home and submissive to her husband is conspicuously supported by the claim of human biology that women are innately nurturing (Weeks, 1985).

The problem is that, like other behavior labeled as deviant, sexual behavior is "constructed from a myriad of human interventions, guided by diverse concepts of what amounts to appropriate behavior." (Weeks, 1985: p53) "When faced with sex," Weeks writes, "we readily abandon respect for diversity and choice, we neglect any duty to understand human motivation and potentialities, and fall back on received pieties, and authoritarian methods" (1985: p53). Michele Foucault's work best explains how institutions of authority and expertise use their power to influence the definition of deviant behavior.

\section{Deviance and Sexuality}

According to Foucault, the church and medical experts have strongly influenced the scope of what society deems to be morally acceptable sex and sexuality and 
conversely what is considered abject deviant behavior. Foucault posits that during the 12th century the Catholic Church began utilizing confession as a means to establish and control sexual morality. By requiring parishioners to confess their intimate sexual behaviors and thoughts, often in great detail, priests used their interpretation of church doctrine to determine not just the morality of the behavior, but defined these behaviors as sin. The priest would then assign what they felt to be a fitting penance for sexual indiscretions (Foucault 1978; Tannahill 1992). It was through these judgments and punishments that the rest of society learned to classify acceptable and deviant sexual behavior (Foucault 1978).

Parishioners shared stories of behaviors and punishments and, combined with church guidance about sexual behavior and deviance, began to form and shape the morality of society. As a result, society became self-regulating and able to label those who engage in unacceptable behaviors as deviant (Foucault 1978). Though the practice of confession continues still today, during the Age of Enlightenment in $18^{\text {th }}$ century logic and secularism displaced the influence of the church on social norms. Society looked to science and medicine to determine right and wrong and soon 'sin' gave way to mental illness, and penance was replaced with treatment (Foucault 1978; Katz 1995).

Foucault writes extensively on how mental health and medical professionals used self-reports or "confessions" to establish morality and deviance through the diagnoses and pathology of behavior (1978). After the transition into the Enlightenment into the $20^{\text {th }}$ century, the behaviors typically deemed abject and deviant concerned women and children. Science and medicine became interested in human reproduction and women were seen as centers of reproduction. Their sexuality became a matter of public and 
scientific importance and in need of control. Predominately, children were believed to be sexual beings, but were in need of control. The medical field worked diligently to control the supposed potentially harmful masturbatory behaviors of young children. Around the same time, the mental health field, due to the influential work of Freud, developed the tool of psychoanalysis which led to psychiatrists pathologizing particular sexual behaviors such as homosexuality that were labeled as perverse or deviant and suggesting cures for these "illnesses" (Foucault 1978; Tannahill 1992; D’Emilio and Freedman 1997). The efforts of Kraft-Ebing to categorized deviant behavior had a significant role in shaping societal definitions of deviance. In this process, Kraft-Ebing classified people by the sexual behaviors they were caught engaging in or arrested for, such as peeping in windows gained one the label of "voyeur" (Kraft-Ebing 1894; Foucault 1978; Tannahill 1992; D'Emilio and Freedman 1997). The labors of science and medicine to control sexuality and define deviance were in attempt to diminish sexuality and sexual behavior in order to create a procreative nature within the confines of marriage. The only socially acceptable sexual behavior was between a married male and female couple for the purposes of procreation; pleasure was deemed irrelevant and too much sex was reasoned to be dangerous and unhealthy. Men were seen as naturally sexual aggressive and women were deemed mainly asexual. However, it was the responsibility and "maternal duty" of the wife to keep the husbands sex drive 'in-check'. Women's desire for sex was believed to be for the purposes of conception (Foucault 1978; Tannahill 1992; D'Emilio and Freedman 1997).

As the Enlightenment gave rise to the Industrial Revolution and capitalism, Foucault notes that the scientific interests in human reproduction and control of sexuality 
evolved into economic concerns, in what he terms as biopower. Foucault suggests biopower manifests in two ways: "ANATOMO -politics of the human body" and "Regulatory controls: a bio-politics of the population." (1978: 139). The first is examination and control over the human body. The body becomes a commodity and means of production. Those in power use the expertise of science and medicine on sexual behavior in effort to control the sexuality of the men, women, and children in an effort to make society more productive and work focused (Foucault, 1978). For example, from the CDC\&P literature mentioned previously, the theory of bio-power might suggest that decreasing the spread of disease and keeping the population healthy may not be the only purpose for the recommendation of reducing the number of sexual partners. Rather, the recommendation is a means to control what is believed to be "overindulgent" sexual behavior so that men and women will be productive and reproductive members of society (see Katz, 1995).

The second manifestation of biopower centers on the notion of reproductive capacity. Economics and politics took a strong interest in population information and statistics. By controlling reproduction, those in power can control the population and work force. Life itself becomes a political force that is measured in demographic statistics. Capitalism and politics, through the regulation of production and population, become the controlling factor of sex and sexuality (Foucault 1978).

\section{Conclusion}

Through consensus and the collective conscience, society establishes values and beliefs that influence how its members think, feel, and act. The collective conscience works to construct what behaviors are deemed normative and deviant (Durkheim 1893, 
1895). In describing these concepts, however, Durkheim fails to address the role of power and institutional forces that influence the values and beliefs of society. Labeling theory suggests that deviance and its labels are constructed primarily within society and social groups, but it also stresses the examination of institutions that influence the definition of deviance in order to exert social control (Lemert 1972; Becker 1973). Foucault (1978) supported this notion in that the development of sexuality as deviance was influenced by the Catholic Church's use of confession and the diagnoses and pathologies of medicine and science. Furthermore, capitalists and politicians use scientific and medical research to subsequently control and regulate the body in order to further their goals (Foucault 1978). Based on this logic, it can be asserted that those in power do in fact have some responsibility for influencing what is deviant and normative and the formulation of the label of deviant behavior.

At this point, it is important to note that the purpose of this study is not to equate promiscuity as deviant behavior. As previously mentioned, science can be an influential force in the definition and establishment of what is deviant. I wished to approach the subject from a sex-positive perspective that avoids demonizing sexual behavior. The discussion of deviance is included here to provide an illustration as to how labels are constructed and how the definitions of these labels are influenced not only by members of a community or society, but also by the institutional forces whose messages are often based on the morality and judgments of the members of that organization. This distinction is important, particularly when discussing the potential consequences of being deemed promiscuous. 


\section{Purpose of Study}

Inevitably and unfortunately, many people are labeled by society as promiscuous or another pejorative slang term. However, the literature fails to define promiscuity in any consistent way. Furthermore, there is a lack of inquiry into the standards individuals use to construct those labels. Society is quick to apply a label of promiscuity to those who behave in a manner that appears outside an arbitrary level of acceptability, particularly women (Reiss 1956; Victor 2004). Even men who do not adhere to society or cultural standards of sexual prudence are labeled as promiscuous (Weeks 1985; Herdt 2009). The issue of definition may seem insignificant until an examination of how promiscuity is used in modern medical and scientific research yields the same ambiguity found in society. Those who perform research are responsible for presenting accurate and value-neutral interpretations of information. By being inconsistent and ambiguous in operationalizations and definitions, the validity and reliability of research is compromised. Also, if researchers are not sensitive to the wording of variable definitions and question construction, they can inadvertently influence the answers of the respondents and subsequently influence the outcome of the research (Rothman, Haddock, and Schwarz 2001; Babbie 2011). Science and medicine must be sensitive to the classification of concepts and behaviors. For example, labeling a sexual behavior as deviant or immoral can be harmful and negatively influence the social definition and consequences of that label (Rothman et al. 2001; Gert and Culver 2009).

Societal standards are established through interaction and consensuses among its members, but experts and authorities are sought to help define normality. Moral entrepreneurs, who often exploit positions of power to influence social movements and 
definitions (bio-power), also look to experts and authorities to legitimize their influence (Lemert 1972, Becker 1973). However, these experts and authorities, particularly those in science and medicine, look to research on society to explain consistencies and infrequencies. Ultimately, the social institutions and the moral entrepreneurs consist of members of the society and are themselves subject to the influential system of interaction. The issue of label definition and construction becomes paradoxical in not knowing where the cycle of definition begins. This is problematic because there are real and serious social consequences for individuals who are labeled as promiscuous, such as slutshaming, harassment, and physical violence.

The purpose of this study is to take an initial step in dismantling the paradox of deviance definition in examining the label of promiscuity from the perspective of the individuals from a non-random sample of people living in a major Midwestern metropolitan area. Given that scientific research and governmental agencies fail to agree upon what constitutes promiscuity, it may be that they are relying on socially generated definitions. In this study, I will examine how individuals personally define promiscuity. I will examine how different demographics, such as age, sex, income, and religiosity effect those definitions. I will determine if an individual's own number of sexual partners affects their perception of promiscuity. And finally, I will show how adherence to the sexual double standard affects the construction of a promiscuous label. Ultimately, the goal is to demonstrate that the same inconsistencies found in the literature are also present among individuals and subsequently neither demographic nor sexual behavioral and attitudinal factors have a significant effect on how an individual defines promiscuity. In the analysis section, I will present findings that suggest that although the terms 
"promiscuous" and the various pejorative labels that convey promiscuity are widely used by science, governmental agencies, and society there is little, if any agreement to the question, "What do you mean I'm a slut!?!. 


\section{CHAPTER IV \\ METHODOLOGY}

\section{Sampling}

The study was conducted using an online survey, consisting of quantitative and qualitative questions, during the Spring 2012 academic semester. The study targeted a volunteer convenience sample from the Louisville-Jefferson County, KY-IN Metropolitan Statistical Area (MSA). This area has an approximate population of $1,290,000$ according the 2010 U.S. Census (U.S. Census Bureau 2010). All survey materials and questions, as well as recruitment methods and materials, were reviewed and approved by the University of Louisville Institutional Review Board prior to their use. (IRB 11.0577)

\section{Recruitment}

Students, faculty, and staff at the University of Louisville (UofL) were recruited using multiple methods such as campus flyers, email bulletins, an advertisement in campus newspaper, The Cardinal, and brief presentations to large lecture classes. The campus flyers were simple pull-tab style flyers (Appendix 1). After each lecture class presentation, interested students were instructed to take a slip of paper from the researcher that presented the same information as the flyer pull-tab. The presentations occurred at the beginning of class and the recruitment materials were left on a table or desk. This was done to protect participant privacy and confidentiality, and all students 
were assured that participation in the study was completely voluntary and that no compensation would be awarded. The campus newspaper advertisement (Appendix 2) was available weekly and online during the recruitment period (from January $27^{\text {th }}$ through March $9^{\text {th }} 2012$ ). The email bulletins (Appendix 3) were sent out to students and faculty every other week during the recruitment period. Additionally, students, faculty, and staff within the Louisville area Kentucky Community and Technical College System (KCTCS) received recruitment materials via email and campus flyers from their Public Relations office. Residents of Louisville were recruited through an advertisement (Appendix 2) in the Leo Weekly Magazine, a popular free progressive local magazine that reports an 85,000 weekly readership (56.9 percent male, and 43.1 percent female; 54.2 percent married; 72 percent between the ages of 25-54) (Kelly 2011). Based on the demographic breakdown of the Leo Weekly readership, recruiting in the weekly magazine balanced the student-heavy recruitment at the University of Louisville and KCTCS and canvassed a wider age and demographic range. The student body of UofL is 70 percent undergraduates that typically fall within the ages of 18-24. Undergraduates also make up 55 percent of the total population of UofL students, faculty, and staff (University of Louisville 2011). The student body of the Louisville area KCTCS consists of 45.9 percent students in the age range 18 to 24 , which is the largest age group and represents 43.2 percent of the total population of Louisville area KCTCS (KCTCS 2012).

\section{Measurement Procedures}

In all recruitment tools, a URL was provided that directed participants to the study page, which was located in the Student Research section of the Sociology Department's website. The study page offered a brief explanation of the study and a link to the 
Informed Consent document. Participants were instructed to read through the informed consent, which explained the goals of the study, detailed the time requirements, and reaffirmed that participants could end the study at any time without penalty. As mentioned above, this study was conducted using an extensive online survey comprised of fixed response (quantitative) and open-ended (qualitative) questions. The list of questions within the survey alternated between quantitative and qualitative measures. The majority of the qualitative measures were follow-up open-ended format questions that provided the respondents areas to expand upon or explain the quantitative answer provided the in the prior question.

\section{Dependent Variables}

The following three variables were selected for their specificity in addressing the main research question: How do people personally define promiscuity?

The central variable examined in this study was comprised of the results from the open-ended question that asked: "How would you personally define promiscuity?" This question was developed specifically for this study. Data for this question were coded using the grounded theory approach to qualitative measures (Charmaz 2006). In grounded theory, an analytic inductive approach is implemented through line-by-line and in vivo coding to identify themes and categories that emerge out of the data based on similar reoccurring responses and the specific language used (Charmaz 2006). The final categories are derived from focused coding that conflates the many codes and smaller categories into fewer, yet more concise and explanatory conceptual memos. A Pearson correlation was conducted for each final category to ensure they were useful for analyzing and interpreting the data (Charmaz 2006). 
The two remaining dependent variables are derived from the questions, "In your opinion, a woman becomes sexually promiscuous when she has had sexual intercourse with___ number of partners?" and "In your opinion, a man becomes sexually

promiscuous when he has had sexual intercourse with___ number of partners?" These questions were modified from a 2010 "Great Male Survey" (GMS) and "Great Female Survey" (GFS) that asked men and women a myriad of questions about lifestyle, politics and sexual behavior, including views on promiscuity (IGN Entertainment 2011 a; IGN Entertainment 2011b). In the GFS, women were asked "At what point does a guy become a "man-whore?" and "At what point does a woman become a slut (IGN Entertainment 2011b)?" In the GMS, men were asked "At what point does a woman become sexually promiscuous?", but did not ask about the promiscuity of men (IGN Entertainment 2011a). Each of the three questions presented in the GFS and GMS offered fixed categorical responses, such as "after he/she sleeps with his/her $10^{\text {th }}$ sex partners" and "never". The responses ranged from $5^{\text {th }}, 10^{\text {th }}$, and $20^{\text {th }}$ up to $100^{\text {th }}$ sex partners, and also featured a "never" category (IGN Entertainment 201 la; IGN Entertainment 2011b). The format of these questions was modified to allow respondents to provide their own promiscuity threshold number, rather than choose from predetermined answers and also gave them the option not to give an answer. The language of these questions was also changed in an attempt to increase objectivity by changing 'man-whore' and 'slut' to 'sexually promiscuous' in both questions.

\section{Independent Variables}

The survey instrument of this study consisted of a multitude of questions that resulted in a myriad of possible variables. The series of demographic questions were 
drawn from a large study conducted at The Kinsey Institute for Research in Sex, Gender, and Reproduction (Janssen, Hahn, Rafaeli, Heiman, Fortenberry, Holtzworth-Munroe, and Katz 2007). These questions were chosen for their expanded categories and inclusivity, but modifications were made to incorporate additional categories such as transgender and intersexed gender identities, queer and pansexual orientations, and nonmonogamous relationship styles (Appendix 4).

For this study, eight demographic variables were chosen for the purposes of analysis: Age, Sex, Race, Education, Income, Marital Status, Sexual Orientation, and Religiosity. These variables were identified as participant characteristics among the promiscuity literature and are typically observed as standard demographic variables found in social science research.

The survey questions also focused on sexual behavior and attitudes. This set of questions was developed or modified from similar previous studies and questionnaires on the sexual behavior, attitudes, and relationship/mating strategies (Buss and Schmitt 1993; Corum 2010). These questions inquired about topics such as relationship status (monogamous vs. non-monogamous), length of current relationship(s), number of sexual partners in one's lifetime, age and activities of first sexual experience (Appendix 4). Given the emphasis on the number of sexual partners in relationship to promiscuity, respondents' own lifetime number of sexual partners was selected as the ninth variable to be used in the various analyses. 


\section{Coding Independent Variables}

Of the ten independent variables, Sex, Race, Marital Status, and Sexual

Orientation were dichotomized. Marital Status and Sexual Orientation was renamed to Relationship Status and Sexuality.

Education was constructed by combining the responses to the questions: "Did you earn a high school or GED?", "Did you attend college or university?", and "What was your highest earned degree?" Each consecutive question is contingent upon a "Yes" from the previous question. The frequency data from the three variables was calculated to construct the different levels of education. Appendix 5 displays the coding schemes and wording for the dichotomized and recoded variables.

Age was calculated from respondents' birthdays and analyzed as an interval variable, ranging from 18 years of age and up. Income, the number of lifetime sexual partners (Renamed LifeSexPart), and Religiosity remained as they were provided by the respondents. Income was a fixed response question that respondents selected their individual yearly income level from categorical answers such as " $\$ 20,000-\$ 29,999 "$ and "\$40,000 - $\$ 49,999 . "$ The categories ranged from "below $\$ 10,000 "$ to " $\$ 100,000$ and above." Religiosity was an interval variable in which respondents expressed how important religion is in their life on a scale from 1 (not at all important) to 10 (very important).

The respondents' scores on a Sexual Double Standard Scale was the tenth and final variable selected for analysis. The Sexual Double Standard Scale score (SDSS score) is an instrument designed to predict an individual's level of adherence to the sexual double standard. A series of 10 items, reflecting the opinions and expectations on 
the sexual behaviors of men and women, is rated on a scale of 1 to $5(1=$ Strongly Agree and $5=$ Strongly Disagree). The SDSS was reverse scored using the sum of all the items and compared to the range of minimum (10) and maximum (50) scores. In this reverse scoring scenario, a minimum of 10 shows that the individual has a low adherence to the sexual double standard and a score of 50 indicates a high level of adherence. A low score indicates that the individual personally believes that men and women have the same sexual agency, but increasing scores suggest that the individual believes women should not be allowed the same sexual freedoms as men (Caron, Davis, Halteman and Stickle 1993).

\section{Quantitative Statistical Analyses}

For statistically comparative and analytical purposes, each of the final qualitative coding categories was coded as a dummy variable. The quantitative measures for the demographics, number of lifetime sexual partners, and SDSS score instruments were expressed in dummy, ordinal, and interval variable coding; the specific coding scheme was contingent on survey results. The final conceptual memos of the qualitative data, the two promiscuity thresholds, and the elected demographic variables were examined in simple descriptive reports and then analyzed using multiple regression procedures. The statistical reports were used to interpret demographic, behavior, or attitudinal consistencies and differences among and between respondents in examining the main research question: How do people personally define the label of promiscuity? 


\section{CHAPTER V}

\section{ANALYSIS}

\section{Sample Characteristics}

A total of 275 respondents completed this study. Of the survey participants, 65 were excluded for either reporting residing in areas other than the Louisville MSA or failing to provide their age. The approval from the Human Subject Committee required respondents over the age of 18 . The remaining 210 respondents was a smaller sample than desired, but given the main goals of the study were qualitative in nature, this number of respondents was acceptable for analysis.

The ages of respondents ranged between 18 and 71, with the mean age of approximately 31 years old (roughly 34 years of age for males and 31 years of age for females). Female respondents outnumbered males almost 2 to $1 ; 136$ (64.8 percent) female and 70 (33.3 percent) male. The majority of survey participants, 65.7 percent, reported education levels between some college and having a bachelor's degree. The mean Religiosity score for this sample is 4.52 and the mean SDSS score was 18.99 . Income was discarded as an independent variable due to colinearity after a Pearson correlation found it to be significantly correlated with age (.684) and education (.460).

For LifeSexPart, a Winsoring procedure, as presented in Buss and Schmitt (1993), were performed, which results in recoding outliers to a lower number based on a high percentage of responses that fall within a specific range. In this case, the outliers were 
recoded to 100 which was the $97^{\text {th }}$ percentile for the number of lifetime sexual partners. The multiple regression analyses explained below were duplicated to test the effects of outliers. However, the duplicated regressions with the Winsored LifeSexPart did not yield significantly different results from the originals. The mean for the Winsored LifeSexPart was approximately 14 and the unadjusted LifeSexPart was approximately 19 . Comparing demographic variables to the Louisville MSA demonstrates similarities to the sample, rather than generalizability. (See Table 1) The racial make-up and median income of the sample match up well with those of the Louisville MSA. The Louisville MSA reports roughly 80 percent whites and 20 percent minorities and the study sample consist of approximately 83 percent whites and 12 percent minorities; the remaining 5 percent either did not know or chose not to answer. The median income for individuals within the Louisville MSA is a little less than $\$ 25,000$ and the median personal income from the study falls within the $\$ 20,000-\$ 29,999$ range. However, given that a large portion of the recruitment efforts were through college campuses, sample demographics, such as age, sex, and education, demonstrate this bias and are reflected in the data in Table 1. 
Table 1. Demographics: Study Sample vs. Louisville MSA

\begin{tabular}{|c|c|c|c|}
\hline & $\begin{array}{c}\text { Study Sample } \\
\text { n (\%) }\end{array}$ & & $\begin{array}{l}\text { Louisville } \\
\text { MSA \%* }\end{array}$ \\
\hline & 210 & $\mathrm{~N}$ & $1,283,566$ \\
\hline \multicolumn{4}{|l|}{ Sex } \\
\hline Male & $70(33.3)$ & & 48.8 \\
\hline Female & $136(64.8)$ & & 51.2 \\
\hline Transgender & $2(1)$ & & $\mathrm{n} / \mathrm{a}$ \\
\hline Other & $2(1)$ & & $\mathrm{n} / \mathrm{a}$ \\
\hline \multicolumn{4}{|l|}{ Age } \\
\hline 18 to 24 & $81(38.6)$ & & 8.5 \\
\hline 24 to 34 & $55(26.2)$ & & 13.4 \\
\hline 35 to 44 & $45(21.4)$ & & 13.5 \\
\hline 45 to 54 & $15(7.1)$ & & 15.3 \\
\hline $55+$ & $14(6.7)$ & & 25.3 \\
\hline \multicolumn{4}{|l|}{ Race } \\
\hline White & $175(83.3)$ & & 80.8 \\
\hline Black & $15(7.1)$ & & 13.7 \\
\hline Latino/Hispanic & $1(.05)$ & & 3.9 \\
\hline Asian & $1(.05)$ & & 1.6 \\
\hline $\begin{array}{r}\text { American Indian/ } \\
\text { Alaskan Native }\end{array}$ & $2(1)$ & & 0.03 \\
\hline \multicolumn{4}{|l|}{ Education } \\
\hline$\leq \mathrm{HS}$ & $9(4.3)$ & & 44.4 \\
\hline $\begin{array}{r}\text { Some College } \\
\text { and AS/AA }\end{array}$ & $75(35.7$ & & 29.8 \\
\hline $\mathrm{BA} / \mathrm{BS}$ & $63(30)$ & & 16.3 \\
\hline Graduate/ & & & \\
\hline Professional & $49(23.3)$ & & 9.6 \\
\hline \multicolumn{4}{|l|}{ Income } \\
\hline Median (Individual) & $\$ 20,000-\$ 29,999$ & & $\$ 24,511$ \\
\hline \multicolumn{4}{|l|}{ Relationship } \\
\hline Single/Never Married & $100(47.6)$ & & 29.9 \\
\hline Married & $50(23.8)$ & & 49.8 \\
\hline Separated/Divorced & $23(11)$ & & 1.8 \\
\hline Cohabitating & $29(13.8)$ & & $\mathrm{n} / \mathrm{a}$ \\
\hline Domestic Partnership & $7(303)$ & & $\mathrm{n} / \mathrm{a}$ \\
\hline Widowed & $1(.5)$ & & 6.1 \\
\hline
\end{tabular}

*US Census Bureau 2010 


\section{Definitions of Promiscuity}

A qualitative analysis of open-ended questions was conducted to determine how participants defined promiscuity. Survey participants were asked "How would you personally define promiscuity?" Each open-ended response was coded using in vivo coding procedures and eight distinct conceptual memos emerged from the data:

$\begin{array}{ll}\text { Partner Number } & \text { Unsafe Sex Practices } \\ \text { Personal Connection } & \text { Refused Response } \\ \text { Time } & \text { Non-categorical } \\ \text { Casual Attitude } & \text { No Answer }\end{array}$

The coding categories Partner Number, Personal Connection, Time, Casual Attitude, and Unsafe Sex Practices were referenced as elements of promiscuity. Refused Response was comprised of responses that expressed unwillingness to define or judge the term "promiscuous." Non-categorical responses were those that did not relate to any of the other referenced elements or perhaps did not make logical sense in relationship to the question. The responses that were left blank were coded as No Answer. (See Table 2) Each response was coded as 1 or 0 (yes or no) depending on which elements of promiscuity were referenced. A single response could be coded into one or more of the categories, for example the response "I would personally define promiscuity as having sex with multiple partners at the same time, without those partners knowing about the others, in or outside of monogamous relationships," could be coded into Partner Number, Time, and Personal Connection. However, for this study the 25 possible conceptual memo combinations were not analyzed, but will be examined in later research. 
Table 2. Promiscuity Conceptual Memos by Frequency and Example

\begin{tabular}{|c|c|c|c|}
\hline & fre. $(\%)$ & $\mathrm{n}^{*}$ & Examples \\
\hline Partner Number & $94(43.7)$ & 210 & $\begin{array}{l}\text { "having multiple sexual partners" } \\
\text { "any one, male or female who willing } \\
\text { chooses to sleep with as many partners as } \\
\text { they can". }\end{array}$ \\
\hline $\begin{array}{l}\text { Personal } \\
\text { Connection }\end{array}$ & $66(30.7)$ & 210 & $\begin{array}{l}\text { "One who has casual, uncomitted, } \\
\text { unemotional sex. } \\
\text { "God \& the Bible describe promiscuity as } \\
\text { any sexual relationship outside of marriage } \\
\text { and I would have to agree at this point in } \\
\text { my life" }\end{array}$ \\
\hline Time & $\begin{array}{c}38 \\
(17.7 \%)\end{array}$ & 210 & $\begin{array}{l}\text { "A sexual partner every } 3 \text { to } 4 \text { months" } \\
\text { "Sleeping with multiple partners } \\
\text { simultaneously." } \\
\text { "Having sex with a different person every } \\
\text { week just makes you irresponsible or a } \\
\text { 'slut.' Every month makes you } \\
\text { promiscuous." }\end{array}$ \\
\hline Casual Attitude & $\begin{array}{c}61 \\
(28.4 \%)\end{array}$ & 210 & $\begin{array}{l}\text { "Fulfilling sexual urges" } \\
\text { "A flippant or care-free attitude toward } \\
\text { sex." } \\
\text { "Being extremely sexual in the way you } \\
\text { talk, act, and present yourself to the } \\
\text { opposite sex." } \\
\text { "Sex with no strings" }\end{array}$ \\
\hline $\begin{array}{l}\text { Unsafe Sex } \\
\text { Practices }\end{array}$ & $34(15.8)$ & 210 & $\begin{array}{l}\text { "I don't care how many partners a person } \\
\text { has as long as they are protected. To me if } \\
\text { you don't use protection or proper } \\
\text { precautions then they are promiscuous." }\end{array}$ \\
\hline Refused Response & $15(7 \%)$ & 210 & $\begin{array}{l}\text { "I don't have a definition for it, because I try } \\
\text { to avoid judging anyone for the number of } \\
\text { sexual partners they've had." } \\
\text { "I don't use the term" }\end{array}$ \\
\hline Non-categorical & $8(3.7 \%)$ & 210 & $\begin{array}{l}\text { "Marylin Monroe" } \\
\text { "Making up for all the sex you won't have } \\
\text { when you're dead." }\end{array}$ \\
\hline No Answer & $15(7 \%)$ & 210 & \\
\hline
\end{tabular}


In order to further explore how an individual defines promiscuity; each conceptual memo was analyzed as a dependent variable in a multiple regression to determine how the categories interacted with the nine independent variables. Only five of the conceptual memos were analyzed: Partner Number, Personal Connection, Time, Casual Attitude, and Unsafe Sex Practices. The remaining three elements were discarded because they did not answer the main research question. The fitness of each model was tested using an ANOVA with $\alpha=0.05$ as the cutoff for significance at a $95 \%$ confidence interval. A multiple regression was considered valid for each model in which the F-score was statistically significant and the $\mathrm{R}^{2}$ was at an acceptable level to explain the variance, which depends on the construction of the model. Of the analyses performed, only the model for Unsafe Sex Practices was significant $\left(\mathrm{R}^{2}=.091, \mathrm{~F}(9,178)=1.976, \mathrm{p}=\right.$ $.045 \leq .05)$

Though only one model was significant, a multiple regression was conducted for all five models to examine the interactions of each of the 9 independent variables within the different models when controlling for the other independent variables. (See tables 37) In the Casual Attitude model (Table 6), Relationship Status was found to be significant $(B=-.172, t=-2.406, p=.017 \leq .05)$, meaning that at a 95 percent confidence level there is an interaction between Relationship Status and individuals that referred to Casual Attitudes in their definition of promiscuity, when controlling for the other variables. The interaction suggests that those who reported not to be in a partnership were more likely to refer to casual attitudes of sex in their definition of promiscuity when controlling for the other variables. 
Table 3. Coefficients: Partner Number

\begin{tabular}{|c|c|c|c|c|c|}
\hline \multirow[b]{2}{*}{ Model } & \multicolumn{2}{|c|}{$\begin{array}{c}\text { Unstandardized } \\
\text { Coefficients }\end{array}$} & \multicolumn{3}{|l|}{$\begin{array}{l}\text { Standardized } \\
\text { Coefficients }\end{array}$} \\
\hline & B & $\begin{array}{l}\text { Std. } \\
\text { Error }\end{array}$ & Beta & $\mathbf{t}$ & Sig. \\
\hline 1 (Constant) & .423 & .197 & & 2.143 & .033 \\
\hline Age & .001 & .004 & .032 & .371 & .711 \\
\hline Sex & -.053 & .081 & -.050 & -.655 & .513 \\
\hline Race & -.125 & .116 & -.083 & -1.074 & .284 \\
\hline Education & -.027 & .030 & -.074 & -.922 & .358 \\
\hline Sexuality & .100 & .089 & .086 & 1.119 & .265 \\
\hline Relationship & .046 & .079 & .046 & .588 & .558 \\
\hline Religiosity & .002 & .012 & .015 & .185 & .853 \\
\hline LifeSexPart & .000 & .001 & .025 & .290 & .772 \\
\hline SDSS score & .005 & .006 & .067 & .853 & .395 \\
\hline
\end{tabular}

Table 4. Coefficients: Personal Connection

\begin{tabular}{|c|c|c|c|c|c|c|}
\hline \multirow{2}{*}{\multicolumn{2}{|c|}{ Model }} & \multicolumn{2}{|c|}{$\begin{array}{l}\text { Unstandardized } \\
\text { Coefficients }\end{array}$} & \multicolumn{3}{|l|}{$\begin{array}{l}\text { Standardized } \\
\text { Coefficients }\end{array}$} \\
\hline & & 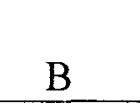 & $\begin{array}{l}\text { Std. } \\
\text { Error }\end{array}$ & Beta & $\mathrm{t}$ & Sig. \\
\hline 1 & (Constant) & .003 & .184 & & .018 & .986 \\
\hline & Age & .004 & .003 & .098 & 1.143 & .255 \\
\hline & Sex & -.090 & .075 & -.091 & -1.195 & .234 \\
\hline & Race & .038 & .108 & .027 & .349 & .728 \\
\hline & Education & .004 & .028 & .011 & .133 & .894 \\
\hline & Sexuality & .115 & .083 & .107 & 1.388 & .167 \\
\hline & Relationship & -.016 & .073 & -.017 & -.215 & .830 \\
\hline & Religiosity & .001 & .011 & .007 & .094 & .925 \\
\hline & LifeSexPart & .000 & .001 & -.021 & -.250 & .803 \\
\hline & SDSS score & .005 & .005 & .070 & .890 & .375 \\
\hline
\end{tabular}

$\left(\mathrm{R}^{2}=.036, \mathrm{~F}(9,178)=.737, \mathrm{p}=.675\right)$ 
Table 5. Regression Coefficients: Time

\begin{tabular}{|c|c|c|c|c|c|}
\hline \multirow[b]{2}{*}{ Model } & \multicolumn{2}{|c|}{$\begin{array}{l}\text { Unstandardized } \\
\text { Coefficients }\end{array}$} & \multicolumn{3}{|l|}{$\begin{array}{l}\text { Standardized } \\
\text { Coefficients }\end{array}$} \\
\hline & $\mathrm{B}$ & $\begin{array}{l}\text { Std. } \\
\text { Error }\end{array}$ & Beta & $t$ & Sig. \\
\hline 1 (Constant) & .140 & .152 & & .919 & .359 \\
\hline Age & .001 & .003 & .027 & .320 & .749 \\
\hline Sex & -.063 & .062 & -.077 & -1.006 & .316 \\
\hline Race & -.086 & .090 & -.074 & -.958 & .340 \\
\hline Education & .006 & .023 & .022 & .278 & .781 \\
\hline Sexuality & .044 & .069 & .050 & .647 & .518 \\
\hline Relationship & .060 & .061 & .076 & .980 & .328 \\
\hline Religiosity & -.015 & .009 & -.127 & -1.613 & .109 \\
\hline LifeSexPart & .000 & .001 & .032 & .382 & .703 \\
\hline SDSS score & .005 & .005 & .085 & 1.083 & .280 \\
\hline
\end{tabular}

Table 6. Regression Coefficients: Casual Attitude

\begin{tabular}{|c|c|c|c|c|c|}
\hline \multirow[b]{2}{*}{ Model } & \multicolumn{2}{|c|}{$\begin{array}{l}\text { Unstandardized } \\
\text { Coefficients }\end{array}$} & \multicolumn{3}{|l|}{$\begin{array}{l}\text { Standardized } \\
\text { Coefficients }\end{array}$} \\
\hline & $\mathrm{B}$ & $\begin{array}{l}\text { Std. } \\
\text { Error }\end{array}$ & Beta & $t$ & Sig. \\
\hline 1 (Constant) & .191 & .179 & & 1.070 & .286 \\
\hline Age & .003 & .003 & .084 & .986 & .325 \\
\hline Sex & -.013 & .073 & -.013 & -.172 & .864 \\
\hline Race & .055 & .105 & .040 & .523 & .602 \\
\hline Education & .014 & .027 & .041 & .517 & .606 \\
\hline Sexuality & -.036 & .081 & -.034 & -.447 & .655 \\
\hline Relationship & -.172 & .071 & -.186 & -2.406 & $.017 *$ \\
\hline Religiosity & .002 & .011 & .013 & .169 & .866 \\
\hline LifeSexPart & -.001 & .001 & -.081 & -.964 & .336 \\
\hline SDSS score & .000 & .005 & .006 & .073 & .942 \\
\hline
\end{tabular}

$\left(\mathrm{R}^{2}=.044, \mathrm{~F}(9,178)=.901, \mathrm{p}=.526\right)$

*Significant at $\mathrm{p} \leq .05$ 
Table 7. Regression Coefficients: Unsafe Sex

\begin{tabular}{|c|c|c|c|c|c|}
\hline \multirow[b]{2}{*}{ Model } & \multicolumn{2}{|c|}{$\begin{array}{l}\text { Unstandardized } \\
\text { Coefficients }\end{array}$} & \multicolumn{3}{|l|}{$\begin{array}{l}\text { Standardized } \\
\text { Coefficients }\end{array}$} \\
\hline & B & $\begin{array}{l}\text { Std. } \\
\text { Error }\end{array}$ & Beta & $\mathrm{t}$ & Sig. \\
\hline 1 (Constant) & .342 & .141 & & 2.416 & .017 \\
\hline Age & -.005 & .003 & -.174 & -2.089 & $.038 *$ \\
\hline Sex & -.003 & .058 & -.003 & -.045 & .964 \\
\hline Race & .022 & .083 & .020 & .262 & .794 \\
\hline Education & .026 & .021 & .095 & 1.212 & .227 \\
\hline Sexuality & .106 & .064 & .124 & 1.663 & .098 \\
\hline Relationship & .055 & .056 & .073 & .967 & .335 \\
\hline Religiosity & .002 & .009 & .015 & .192 & .848 \\
\hline LifeSexPart & .001 & .001 & .138 & 1.682 & .094 \\
\hline SDSS score & -.013 & .004 & -.232 & -3.053 & $.003 * *$ \\
\hline
\end{tabular}

In the Unsafe Sex model (Table 7), Age $(\mathrm{B}=-.005, \mathrm{t}=-2.089, \mathrm{p}=.038 \leq .05)$ and SDSS score $(B=-.013, t=-3.053, p=.003 \leq .01)$ were significant, which means at $99 \%$ confidence level there is an interaction between the factors Age, SDSS score and Unsafe Sex when controlling for the other variables. A Pearson correlation was conducted to test for colinearity between Age and SDSS score, but the correlation was not significant $($ Pearson $=.025)$. The interaction between Age and the Unsafe Sex category implies that as Age increases individuals are less likely to refer to unsafe sex practices in their definition of promiscuity. The second interaction shows that as SDSS score decreases, meaning lower adherence to the sexual double standard, the individual is more likely to refer to unsafe sex practices in their definition promiscuity.

The remaining models were not found to be significant. To verify these interactions, additional multiple regressions were conducted that split the models into 
demographic variables and behavior/attitudinal variables. The demographic models consisted of Age, Sex, Race, Education, Sexuality, and Partnership. The behavior/attitudinal models consisted of Religiosity, Number of Lifetime Sexual Partners, and SDSS Score. However, the same results were concluded for all five dependent and all nine independent variables after performing the split model regressions.

\section{Quantifying Promiscuity}

As a result of the many references to "multiple" or "high number of sexual partners" in the literature and fact that $43.7 \%$ of respondents referred to Partner Number in their definition of promiscuity, the number of sexual partners is an inescapable aspect of promiscuity. This analysis examined the threshold number of sexual partners that constitutes promiscuity and which of the nine independent variables influenced the suggested number.

In the question regarding promiscuity thresholds, respondents were also given the option not to answer, which $98(46.7 \%)$ and $99(47.1 \%)$ did not provide an answer for a woman and a man, respectively. In the raw data, 92 percent of all partner number scores were 100 or below for both variables. Winsoring procedure was performed to recode the outliers to 100. Of the recoded data from respondents that did provide an answer, the mean threshold of promiscuity was approximately 15 for women and 17 for men. Table 8 displays the mean thresholds for the demographic variables Age (by groups), Sex, Race, Education, Sexuality and Relationship Status.

A multiple regression was performed to examine the interactions between the nine independent variables (Age, Sex, Race [White/Nonwhite], Education, Sexuality [Heterosexual/Non-Heterosexual], Relationship Status [Partnership/No Partnership], 
Religiosity, Number of Lifetime Sexual Partners [LifeSexPart], and SDSS Score) and the two reported promiscuity thresholds.

Table 8. Promiscuity Threshold by Age, Sex, Race, Education, Sexuality, Relationship Status

\begin{tabular}{ccccccc}
\hline & Woman & & & Man & \\
$\mathrm{n} *$ & Mean & S.D. Median & $\mathrm{n} *$ & Mean & S.D. Median \\
\hline
\end{tabular}

Age

$\begin{array}{rcccccccc}18 \text { to } 24 & 45 & 15.09 & 27.067 & 7 & 44 & 15.73 & 27.338 & 7 \\ 24 \text { to } 34 & 29 & 18.07 & 29.313 & 7 & 29 & 18.41 & 29.304 & 7 \\ 35 \text { to } 44 & 23 & 17.13 & 16.672 & 15 & 23 & 17.78 & 13.591 & 15 \\ 45 \text { to } 54 & 7 & 10.29 & 9.25 & 10 & 7 & 22.57 & 35.505 & 10 \\ 55+ & 8 & 6.38 & 11.771 & 2 & 8 & 7.38 & 12.165 & 2\end{array}$

Sex

$\begin{array}{rcccccccc}\text { Male } & 67 & 18.39 & 29 & 10 & 66 & 18.88 & 29.218 & 10 \\ \text { Female } & 45 & 10.87 & 11.644 & 7 & 45 & 13.47 & 17.62 & 1\end{array}$

Race

$\begin{array}{rcccccccc}\text { White } & 92 & 12.98 & 20.570 & 7 & 92 & 13.533 & 20.650 & 7.00 \\ \text { Nonwhite } & 15 & 32.13 & 37.007 & 15 & 14 & 40.000 & 41.126 & 20.00\end{array}$

Education

$\begin{array}{rcccccccc}\leq \text { HS } & 7 & 10.00 & 9.469 & 10.00 & 7 & 9.71 & 9.742 & 10.00 \\ \text { Some College } & 30 & 22.17 & 32.612 & 10.00 & 30 & 22.70 & 32.559 & 10.00 \\ \text { AS/AA } & 9 & 22.11 & 32.713 & 10.00 & 9 & 23.22 & 32.418 & 10.00 \\ \text { BA/BS } & 35 & 14.03 & 22.901 & 7.00 & 34 & 14.44 & 23.206 & 7.00 \\ \text { MS/MA } & 23 & 9.83 & 8.726 & 6.00 & 23 & 13.74 & 20.785 & 6.00 \\ \text { Ph.D/MD } & 4 & 10.00 & 10.801 & 7.50 & 4 & 13.750 & 11.087 & 15.00\end{array}$

Sexuality

$\begin{array}{rcccccccc}\text { Hetero } & 89 & 10.74 & 15.578 & 7.00 & 88 & 11.45 & 15.864 & 7.00 \\ \text { NonHetero } & 23 & 33.22 & 38.387 & 15.00 & 23 & 36.70 & 40.690 & 15.00\end{array}$

Relationship

$\begin{array}{lllllllll}\text { Partnership } & 47 & 13.00 & 17.210 & 10.00 & 46 & 13.85 & 17.383 & 10.00\end{array}$

$\begin{array}{lllllllll}\text { No Partnership } & 65 & 17.06 & 27.651 & 10.00 & 65 & 18.69 & 29.503 & 8.00\end{array}$

${ }^{*} n=112$ for Woman threshold, 111 for Man threshold 


\section{Promiscuity threshold for a Woman}

In this model, $\mathrm{n}=106$ after a pairwise deletion. An ANOVA test of fitness concluded that the model was statistically significant at a 99 percent confidence level and explains 36.9 percent of the variance $\left(\mathrm{R}^{2}=.369, \mathrm{~F}(9,97)=6.313, \mathrm{p}=.000 \leq .001\right)$. The results of the multiple regression (see Table 9) demonstrated an interaction between the constant (Woman Promiscuity Threshold) and Race, Sexuality, and Religiosity. Each interaction was significant at the 99.9 percent confidence level: $R$ ace $(B=-25.239, t=-$ 4.157, $\mathrm{p} \leq .000<.001)$, Sexuality $(\mathrm{B}=-19.563, \mathrm{t}=-4.216, \mathrm{p} \leq .000<.001)$, Religiosity $(\mathrm{B}=-$ $2.535, \mathrm{t}=-3.952, \mathrm{p} \leq .000<.001)$. The significant interaction between Race and Woman Promiscuity Threshold suggests that mean threshold increases by 25.239 for nonwhites when compared to that of whites and when controlling for the other variables. The threshold for female promiscuity increases by 19.563 for non-heterosexuals when compared to that of heterosexuals when controlling for the other variables. Lastly, the Woman Promiscuity Threshold decreases by 2.111 for every one unit increase of Religiosity. Thus, as the importance religious or spiritual beliefs increase, the threshold of promiscuity decreases by 2.111 . 


\begin{tabular}{|c|c|c|c|c|c|}
\hline \multirow[b]{2}{*}{ Model } & \multicolumn{2}{|c|}{$\begin{array}{l}\text { Unstandardized } \\
\text { Coefficients } \\
\text { Std. }\end{array}$} & \multirow{2}{*}{$\begin{array}{c}\text { Standardized } \\
\text { Coefficients } \\
\text { Beta }\end{array}$} & \multirow[b]{2}{*}{$\mathrm{t}$} & \multirow[b]{2}{*}{ Sig. } \\
\hline & B & $\begin{array}{l}\text { Std. } \\
\text { Error }\end{array}$ & & & \\
\hline 1 (Constant) & 64.257 & 10.299 & & 6.239 & .000 \\
\hline Age & .201 & .189 & .100 & 1.067 & .288 \\
\hline Sex & -8.147 & 4.206 & -.162 & -1.937 & .056 \\
\hline Race & -25.239 & 6.072 & -.351 & -4.157 & $.000 * * *$ \\
\hline Education & -2.385 & 1.550 & -.135 & -1.538 & .127 \\
\hline Sexuality & -19.563 & 4.640 & -.355 & -4.216 & $.000 * * *$ \\
\hline Relationship & -2.111 & 4.111 & -.044 & -.514 & .609 \\
\hline Religiosity & -2.535 & .641 & -.340 & -3.952 & $.000^{* * *}$ \\
\hline LifeSexPart & -.043 & .046 & -.087 & -.937 & .351 \\
\hline SDSSscore & .298 & .308 & .083 & .969 & .335 \\
\hline
\end{tabular}

\section{Promiscuity Threshold for a Man}

This model's sample size was 105 after a pairwise deletion. An ANOVA test of fitness concluded that the model was statistically significant at a 99.9 percent confidence and explains 40.9 percent of the variance $\left(R^{2}=.409, F(9,96)=6.313, p \leq .000<.001\right)$. Table 10 displays the results of the multiple regression. The regression demonstrated interactions between the constant (Man Promiscuity Threshold) and Race, Sexuality, and Religiosity. Each interaction was significant at the 95 percent confidence level: Race $(B=-30.582, t=-4.891, p \leq .000<.01)$, Sexuality $(B=-21.132, t=-4.4224 .216, p \leq .000<.001)$, Religiosity $(\mathrm{B}=-2.534, \mathrm{t}=-3.837, \mathrm{p} \leq .000<.001)$. The interaction between Race and Man Promiscuity Threshold was shown to be significant and suggests that average threshold for non-whites increases by 30.582 when compared to that of whites and when controlling for the other variables. Sexuality interacted with Man Promiscuity Threshold 
in that the threshold for non-heterosexuals increases by 21.132 when compared to that of heterosexual and when controlling for the other variables. Finally, in the interaction Religiosity, the Man Promiscuity Threshold decreases by 2.534 for every one unit of increase of Religiosity. Thus, as the importance of religious or spiritual beliefs increases, the threshold of promiscuity decreases by 2.534 .

Table 10. Regression Coefficients Promiscuity Threshold: Man

\begin{tabular}{|c|c|c|c|c|c|}
\hline \multirow[b]{2}{*}{ Model } & \multicolumn{2}{|c|}{$\begin{array}{l}\text { Unstandardized } \\
\text { Coefficients }\end{array}$} & \multirow{2}{*}{$\begin{array}{c}\text { Standardized } \\
\text { Coefficients } \\
\text { Beta }\end{array}$} & \multirow[b]{2}{*}{$\mathrm{t}$} & \multirow[b]{2}{*}{ Sig. } \\
\hline & 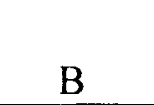 & $\begin{array}{l}\text { Std. } \\
\text { Error }\end{array}$ & & & \\
\hline 1 (Constant) & 65.435 & 10.605 & & 6.170 & .000 \\
\hline Age & .207 & .194 & .097 & 1.064 & .290 \\
\hline Sex & -8.054 & 4.331 & -.152 & -1.859 & .066 \\
\hline Race & -30.582 & 6.253 & -.402 & -4.891 & $.000_{* * *}$ \\
\hline Education & -2.065 & 1.596 & -.111 & -1.293 & .199 \\
\hline Sexuality & -21.132 & 4.778 & -.363 & -4.422 & $.000^{* * *}$ \\
\hline Relationship & -3.199 & 4.233 & -.063 & -.756 & .452 \\
\hline Religiosity & -2.534 & .660 & -.322 & -3.837 & $.000^{* * *}$ \\
\hline LifeSexPart & .020 & .048 & .037 & .410 & .683 \\
\hline SDSS score & .509 & .317 & .134 & 1.605 & .112 \\
\hline
\end{tabular}




\section{CHAPTER VI \\ DISCUSSION AND CONCLUSION}

The concept of promiscuity has been ambiguously defined and inconsistently operationalized in scientific and medical research. Until now, the use of the term promiscuity has not been analyzed, critiqued, or clearly defined. The goal of this study was to investigate what factors influence definitions of promiscuity. Specifically, the research addressed the question of how individuals personally define promiscuity. A second purpose of the project was to draw attention to the inconsistent definitions used in research and the resulting nebulous definitions used by society.

To answer this question, I conducted a mixed methods online survey on sexual behavior and attitudes. I employed multiple recruitment methods to gain respondents from the University of Louisville, The Louisville area KCTCS, and the Louisville Metropolitan area. The respondents of this study ranged in age from 18 to 71 and came from a variety of races, educational levels, religious and spiritual beliefs, and sexualities. The sample collected was a convenience sample, which limits the generalizability of the sample and data. However, the main qualitative aspect of the study gives credence to the data.

Ideas derived from labeling theory and the concepts of the collective conscience and biopower demonstrate that definitions of deviance emerge from a paradoxical process of interaction. Deviance is defined by what society agrees is unacceptable 
behavior, yet the collective conscience is weaker in complex societies than those more homogeneous. However, labeling theory and biopower also explain that social institutions and moral entrepreneurs exploit positions of power and authority to influence the definitions of acceptable and deviant behavior. Experts and authorities become vehicles that influence the rest of society. The paradoxical aspect of this interaction occurs when science and medicine look to research on society to provide support for their arguments. The origin of the definition of deviance becomes lost in the cycle. Evidence of this paradox can be seen when juxtaposing the academic literature and the results of this study. We know the claims made by scientific research influence social definitions. We also know that in order to perform medical and social science research, researchers must collect the data from society. However, it is unclear whether scientific research or society is responsible for perpetuating the ambiguous definitions of promiscuity.

The qualitative analysis on the promiscuity definitions provided by the respondents showed the same inconsistencies found in the literature. Individuals had different interpretations of the standards of acceptable levels of sexual activity. Some individuals believed, just as in examples from the literature, that promiscuity is based on a specific number of sexual partners one has in their lifetime. Others felt that the number of sexual partners is relative to the age of the individual, multiple concurrent partners, or partners over a specified length of time (weeks, months, years).

Many respondents felt that promiscuity was related to a personal connection with sexual partners. Their definitions ranged from cheating on a significant other or spouse to sex while not in a relationship. Additionally, respondents stated that having sex with someone you did not have a personal connection with or anonymous sex was to be 
considered promiscuous behavior. Though "one-night stands" were mentioned as promiscuous, the study failed to define how many one-night stands constituted promiscuity. It was also suggested by a few respondents that promiscuity was having a lax or flippant attitude about sex, sex for the sake of sex, or simply engaging in flirtatious behavior and presenting oneself in a sexual way.

The definitions of promiscuity differ slightly between the literature and respondents in reference to unsafe sex practices. Research suggests that risk of STIs and HIV increase with the number of sexual partners, but several survey participants asserted that unsafe sex practices are an element of promiscuity. Some of these respondents state that promiscuity is having unprotected sexual intercourse with several sexual partners with no attachment, while others justify having multiple sexual partners and even anonymous sex as long as the individual is practicing safe sex. Though discarded from the main analysis, a noteworthy addition to the definition of promiscuity, are the few individuals that were unwilling to provide a definition. These individuals voiced adamant aversion to the use of the term. Some respondents reported that they did not feel it was their place to judge the sexual behaviors of others.

A quantitative analysis was performed on the different definition categories to examine if social factors influenced how individuals constructed their definitions. Only one of the regression models was significant; only two variables in all the models were significant. In the model for Casual Attitudes, those not in a partnership or relationship were more likely to refer to casual attitudes as an element of promiscuity. One interpretation might suggest that these individuals are looking for a partnership and having a casual attitude about sex would not be considered conducive to a long-term 
partnership. This interpretation is supported by Buss and Schmitt (1993) who claim that promiscuity is an undesirable trait when seeking a long-term relationship.

SDSS score was the only statistically significant interaction with unsafe sex. Scoring low on the Sexual Double Standard Scale means the individual has lower adherence to the sexual double standard, implying that the individual believes that men and women have the same sexual agency. This interaction implies that those with a low SDSS score are more likely to refer unsafe sex practices as an element of promiscuity. These individuals may have a more progressive attitude toward sex and sexuality. This progressive attitude may position safe or responsible sex over the conventional idea that sex requires a personal connection or a limited number of partners.

The conceptual memos found various explanations and inconsistencies on the definition of promiscuity, but there were social factors that influenced the numeric threshold of promiscuity. In addition to providing personal definitions, survey participants were asked to give a number of sexual partners at which they believed a man and a woman become promiscuous. Only one half of the survey participants provided a number. For both sexes, Race, Sexuality and Religiosity appeared to have a statistically significant influence the threshold of promiscuity

The interaction between the promiscuity thresholds and Race is intriguing. At an initial glace, this interaction might be the result of some minorities reporting more sexual partners than whites (Santelli et al. 1998; Rowe 2002) By comparing the means of white and non-whites, the data did not find statistical significant to supports this claim $(t(196)=-$ $1.885, \mathrm{p}=.061>.05$ ). Additionally, in the same regression model, the number of lifetime sexual partners was not a significant factor influencing the promiscuity threshold. An 
alternative explanation for the difference between whites and non-whites might be the result of more conservative values among the white population of the particular research area. Less surprising was the higher promiscuity threshold for those that identify as nonheterosexual. More progressive sexual attitudes among the LGBTQ community may have influenced the non-heterosexual group's increased promiscuity thresholds for both sexes. Lastly, the interaction of the promiscuity thresholds with religiosity shows that as the importance of religion and spirituality increases the threshold of promiscuity decreases. As expected, those who adhere to more traditional religious views also have more conservative views on sex and sexuality. These results suggest that in quantifying promiscuity, race, sexuality, and religiosity play a role. These findings do lend support for the argument that social institutions and moral entrepreneur influence the definition of promiscuity. An interpretation of the results of these two regressions demonstrates the influence of white, Christian, hetero-normativity that is the dominant discourse in this area.

Ultimately, the myriad of definitions in both the literature and opened-ended responses presented in this study support the argument that promiscuity is an abstract and nebulous concept for which there is no universal definition or conclusive standard. The attempt to quantify promiscuity in relation to the number of sexual partners did yield a few social factors that influenced the threshold, but supports the notion that social institutions influence the construction of our definitions. In light of these findings, the assertion can be made to challenge and restrict the use of the term "promiscuity" and its pejorative allusions. 
Concepts that are not clearly defined make for difficult research and poor scientific standards. Durkheim argues, "The better a structure is articulated, the more it offers a healthy resistance to all modification" (1895; as quoted in Edles and Appelrouth 2010: 101). Clarification is necessary to address misunderstandings, and the different personal meanings and definitions behind the label of promiscuity cause a great deal of misunderstanding. The term promiscuity and its derivatives are continuously and commonly used despite the lack of a universal meaning. The severe social consequences associated with these terms are amplified by these inconsistencies. An example of these consequences occurred on February 27, 2012. Conservative radio host Rush Limbaugh called Georgetown law student Sandra Fluke "a slut" after she testified in front of Congress in support of a Department of Health and Human Services directive that all insurance companies be required to cover contraception free of charge. Limbaugh also referred to her as a prostitute (Fard 2012). In his comments, Limbaugh suggested that women who were in support of birth control coverage with no co-payment could not afford the contraception for "all the sex they were having." Aside from Rush's ignorance on the subject of female contraception, his comments made an impact in the media. A large number of people contested his outburst, but a number of individuals also agreed with Limbaugh; these people felt that young women having sex outside of marriage was "promiscuous" and "slutty." Limbaugh did not offer a concise definition of the term "slut", but the insult was no less harming. Despite Limbaugh's less-than-sincere apology, Sandra Fluke may find it difficult to escape the unfairly ascribed label. By not challenging the ambiguous values of convention, we may be forced to live under a moral agenda that may not be our own. 
Future research should continue to examine and compare how promiscuity is defined in different social and cultural demographics in order to deconstruct the factors that influence those definitions. Additionally, further examination of the moral entrepreneurs and institutional forces that influence society is the key to deconstructing the definitions of promiscuity. "It would never have been possible to establish the freedom of thought we now enjoy if the regulations prohibiting it had not been violated before being solemnly abrogated" (Durkheim 1895; as quoted in Edles and Appelrouth 2010: 101). In this sense, sexual freedom cannot be obtained without challenging and violating the confining and ambiguous definitions used by those in power to control our sexual behavior and pleasure. We owe it to ourselves to deconstruct all aspects of convention to ensure the rules governing society are not the moral agenda of a select few.

\section{Limitations}

Ultimately, research of a sexual nature will be met with the difficulty of social taboos surrounding public discussions of sex and sexual behavior. However, other factors may have also impeded the study. Since literature discussing specifically how people define and construct the label of promiscuity is scant, if existent at all, many of the variables were developed specifically for this study, which can limit their reliability and validity. I utilized a mixed methods approach and triangulation to affirm reliability. There are also often inaccuracies among men and women in self-reporting sexual behavior. Men tend to over-report and women under-report their number of lifetime sexual partners (Smith 1992; Jaccard, Wan, Guilamo-Ramos, Dittus, and Quinlan 2004). To address any possible inconsistencies due to this tendency, the self-reported numbers in this study were compared to averages found in previous studies in order to verify validity. 
This research is specific to the Louisville Metro area and the 210 volunteer respondents with computer and internet access who were willing to participate in a research study on sexual behavior. Additionally, the majority of recruitment occurred on college campuses and through a progressive weekly magazine which may result in a sample bias towards more sexually progressive attitudes. However, research on sexual behavior and attitudes with volunteer samples that were criticized and contested for their reliability, like Kinsey's findings $(1948,1953)$, have been cited as support in subsequent studies (Laumann, Gagnon, Michael, and Michaels 1994). The mixed methods approach to this project is not necessarily generalizability, but rather to examine the interrelationships and dissimilarities in the attitudes and perspectives of individuals and provide a spring board for future research on deconstructing promiscuity and other labels of deviance. 


\section{REFERENCES}

Antecol, Heather and Kelly Bedard. 20047. "Does single parenthood increase the probability of teenage promiscuity, substance use, and crime?" Journal of Population Economics 20(1): 55-71.

Anonymous. 1949. "Post-Kinsey: Voluntary Sex Relations as Criminal Offences." The University of Chicago Law Review 17(1):162-182.

Anonymous. 2002. "National Council on Sexual Addiction and Compulsivity (NCSAC) 2002. Information Statement: Women Sex Addicts." Sexual Addiction and Compulsivity 9: 293-295.

Babbie, Earl. 2011. The Basics of Social Research, $5^{\text {th }} \mathrm{ed}$. Belmont CA. Wadsworth.

Barash, David. P. and Judith. E. Lipton. 2001. The Myth of Monogamy: Fidelity and Infidelity in Animals and People. New York, NY. Freeman.

Becker, Howard. 1973. Outsiders. New York. NY. The Free Press.

Benatar, David. 2002. "Two Views of Sexual Ethic." Public Affairs Quarterly 16(3): 191-201.

Bingenheimer, Jeffrey B. and Arline T. Geronimus. 2009. Behavioral Mechanisms in HIV Epidemiology and Prevention: Past, Present, and Future Role." Studies in Family Planning 40(3): 187-204.

Buss, David M. and David P. Schmitt. 1993. "Sexual Strategies Theory: An Evolutionary Perspective on Human Mating." Psychological Review 100(2): 204-232.

Caron, S. L., C. M. Davis, W. A. Haltman, and M. Stickle. 1993. "Predictors of CondomRelated Behavior among First-Year College Students." The Journal of Sex Research 30: 252-259.

Catania, J. A, D. Binson, M.M. Dolcini, R. Stall, K. Choi, L. M. Pollack, E. S. Hudes, J. Canshola, K. Phillips, J. T. Moskowitz, and T. J. Coates. 1995. "Risk Factors for HIV and Other Sexually Transmitted Diseases and Prevention Practices among US Heterosexual Adults: Changes from 1990 to 1992." American Journal of Public Health 85:1492-1499. 
Chandra, Anjani, Ph.D., Veena G. Billioux, Sc.M., Casey E. Copen, Ph.D, and Catlainn Sionean, Ph.D. 2012. "HIV Risk-Related Behaviors in the United States Household Population Aged 15-44 Years: Data from the National Survey of Family Growth, 2002 and 2006-2010 (National Center for HIV/AIDS, Viral Hepititis, STD, and TB Prevention)." National Health Statistics Report. 46.

Charmaz, Kathy. 2006. Constructing Grounded Theory: A Practical Guide Through Qualitative Research. London. Sage Publishing.

Clayton, Krisstal D. and David Trafimow. 2007. "A Test of Three Hypotheses Concerning Attributions toward Female Promiscuity." The Social Science Journal 44: 677-686.

Corum, Joshua O., 2010. University of Louisville "The Sexual Double Standard Revisited: Men and Women's Attitudes Toward a Potential Partner's Sexual History." Paper presented at the 2010 Anthropologists and Sociologists of Kentucky (ASK) Annual Meeting, Lindsey Wilson College Columbia, Kentucky.

Crawford, Mary and Danielle Popp. 2003. "Sexual Double Standards: A Review and Methodology Critique of Two Decades of Research. Journal of Sex Research 40(1): 13-27.

D’Emilio, John D. and Estelle B. Freedman. 1997. Intimate Matters. A History of Sexuality in America. $2^{\text {nd }}$ ed. Chicago, IL. The University of Chicago Press.

DeLamater, John. 1981. "The Social Control of Sexuality." Annual Review of Sociology 7: $263-290$.

Delavande, Adeline, Dana Goldman and Neeraj Sood. 2010. "Criminal Prosecution and Human Immunodeficiency Virus-Related Risky Behavior." Journal of Law and Economics 53(4): 741-782.

Desiderato, Laurie and Helen J. Crawford. 1995. "Risky Sexual Behavior in College Students: Relationships Between number of Sexual Partners, Disclosure of Previous Risky Behavior, and Alcohol Use." Journal of Youth and Adolescence 24(1): 55-68.

Diamond, Sara. 1989. Spiritual Warfare. The Politics of the Christian Right. Boston, MA. South End Press.

Durkheim, Emile. 1893. The Division of Labor. France. The Free Press.

Durkheim, Emile. 1895. The Rules of Sociological Method. France. The Free Press.

Edles, Laura Defor and Scott Appelrouth. 2010. Sociological Theory in the Classical Era: Text and Readings Second Edition. Thousand Oaks, CA. Pine Forge Press. 
Ellis, Albert. 1968, "The Changing American People: Are We Deteriorating or Improving?" Annals of the American Academy of Political and Social Science 378: 58-67.

Fard, Maggie Fazelli. 2012. "Sandra Fluke, Georgetown student called a 'slut' by Rush Limbaugh, speaks out." The Washington Post. Retrieved on April 12, 2012. (http://www.washingtonpost.com/blogs/the-buzz/post/rush-limbaugh-callsgeorgetown-student-sandra-fluke-a-slut-for-advocating contraception/2012/03/02/gIQAvjfSmR_blog.html)

Farrington, David P. 1998. "Predictors, Causes, and Correlates of Male Youth Violence Source." Crime and Justice 24: 421-475.

Foucault, Michel. 1978. The History of Sexuality Volume 1: An Introduction. New York, NY. Random House, Inc.

Gert, Bernard and Charles M. Culver. 2009. "Sex, Immorality, and Mental Disorders." Journal of Medicine and Philosophy 34: 487-495.

Goode, Erich. 2001. Deviance Behavior, $6^{\text {th }}$ ed. Upper Saddle River, NJ. Prentice-Press.

Harper, Douglas 2012. "Online Etymology Dictionary." Retrieved April 1, 2012. (http:// http://www.etymonline.com).

Harris, Grant T., Tracey A. Skilling, and Marnie E. Rice. 2001. "The Construct of Psychopathy" Crime and Justice 28: 197-264.

Herdt, Gilbert. 2009. Moral Panics, Sex Panics: Fear and the Fight over Sexual Rights. New York, NY. New York University Press.

IGN Entertainment. 2011a. "Great Male Survey: 2011 Edition." Retrieved January 15, 2012. http://www.askmen.com/specials/great_male_survey/.

IGN Entertainment. 2011b. "Great Female Survey: 2011 Edition." Retrieved January 15, 2012. http://www.askmen.com/specials/great_male_survey/.

Jaccard, James, Choi K. Wan, Vincent Guilamo-Ramos, Patricia Dittus, and Shannon Quinlan. 2004. "Recalling Sexual Partners: The Accuracy of Self-Reports." Journal of Health Psychology 9(6): 699-712. 
Janssen, E, S. Hahn, E. Rafaeli, J. R. Heiman, D. Fortenberry, A. Holtzworth-Munroe, and B. Katz, 2007. "Affect: Men and women's mood and sexual desire and their effects on risk-taking and relationships." In Janssen, E., (Symposium chair), Quad-A meets Quad-S: Current Research at The Kinsey Institute on Attraction, Arousal, Affect, and Aggression. Paper presented at the $50^{\text {th }}$ Annual Meeting of the Society for the Scientific Study of Sexuality, Indianapolis, IN.

Kafka, Martin P. 2001. "The Paraphilia-Related Disorders: A Proposal for a Unified Classification of Nonparaphilic Hypersexuality." Disorders Sexual Addiction and Compulsivity 8: 227-239.

Katz, Jonathan. 1995. The Invention of Heterosexuality. New York, NY. Plume.

Kelly, Sarah. 2011. "Leo Weekly 2011 Media Kit." Leo Weekly Magazine Retrieved on January 15, 2012 from http://leoweekly.com.

Kentucky Community and Technical College System (KCTCS) 2012. "Fall Enrollment" compiled by the Office of Research and Policy Analysis. Retrieved on January 15, 2012 from http://www.kctcs.edu/en/About_KCTCS/Institutional_Research.aspx

Kinsey, Alfred, Wardell Pomeroy, and Clyde Martin. 1948. Sexual Behavior in the Human Male, Philadelphia, PA. Saunders.

Kinsey, Alfred, Wardell Pomeroy, Clyde Martin, and Paul Gebhard. 1953. Sexual Behavior in the Human Female, Philadelphia, PA. Saunders.

Kraft-Ebing, Richard. 1894. Psychopathia Sexualis. Philadelphia, PA. The F. A. Davis Company.

Kreager, Derek A. and Jeremy Staff. 2009. "The Sexual Double Standard and Adolescent Peer Acceptance." Social Psychology Quarterly 72(2): 143-164.

La France, Betty H., David D. Henningsen, Aubrey Oates, and Christina M. Shaw. 2009. "Social Sexual Interactions? Meta-Analyses of Sex Differences in Perceptions of Flirtatiousness, Seductiveness, and Promiscuousness." Communication Monographs 76(3): 263-285.

Laumann, Edward O., John H. Gagnon, Robert T. Michael, and Stuart Michaels. 1994. The Social Organization of Sexuality Chicago, IL. The University of Chicago Press.

Lemert, Edwin M. 1972. Human Deviance, Social Problems, and Social Control $2^{\text {nd }}$ ed. Englewood Cliffs, NJ. Prentice-Hall Inc.

Markey, Patrick M. and Charlotte N. Markey. 2007. "The Interpersonal Meaning of Sexual Promiscuity." Journal of Research in Personality 41: 1199-1212. 
Marks, Michael. J. and R. Chris Fraley. 2005. "The Sexual Double Standard: Fact or Fiction?" Sex Roles 52(3\&4): 175-186.

Martin, John L. 1996. "Structuring the Sexual Revolution." Theory and Society 25(1): 105-151.

McCaghy, Charles H., Timothy A. Capron, and J.D. Jamieson. 2003. Deviant Behavior: Crime, Conflict, and Interest Groups. Boston, MA. Pearson Education, Inc.

Meston, Cindy M., Julia R. Heiman, and Paul D. Trapnell. 1999. "The Relation between Early Abuse and Adult Sexuality." The Journal of Sex Research 36(4): 385-395.

Molina, José-Alberto and Rosa Duarte. 2006. "Risk Determinants of Suicide Attempts among Adolescents American." Journal of Economics and Sociology 65(2): 407 434.

Pope, Hallowell and Dean D. Knudsen 1965. "Premarital Sexual Norms, the Family, and Social Change." Journal of Marriage and Family 27(3) (Aug., 1965): 314-323.

Reiss, Ira. L. 1956. "The Double Standard in Premarital Sexual Intercourse: A Neglected Concept." Social Forces 34(3): 224-230.

Rothman, Alexander J., Geoffery Haddock, and Norbert Schwarz. 2001. "“How Many Partners Is Too Many?" Shaping Perceptions of Personal Vulnerability." Journal of Applied Social Psychology 31(10): 2195-2214.

Robinson, Ira, Edward Robinson, Ken Ziss, Bill Ganza and Stuart Katz. 1991. "Twenty Years of the Sexual Revolution, 1965-1985: An Update" Journal of Marriage and the Family 53(1): 216-220.

Rowe, David C. 2002. "IQ, Birth Weight, and Number of Sexual Partners in White, African American, and Mixed Race Adolescents." Population and Environment 23(6): 513-524.

Ryan, Christopher and Cacilda Jethá 2010. Sex at Dawn. New York, NY. HarperCollins Publishers.

Santelli, John, S., Nancy D. Brener, Richard Lowry, Amita Bhatt and Laurie S. Zabin. 1998. "Multiple Sexual Partners among U.S. Adolescents and Young Adults." Family Planning Perspectives 30(6): 271-275.

Schmitt, David P. 2004. "The Big Five Related to Risky Sexual Behaviour Across 10 World Regions: Differential Personality Associations of Sexual Promiscuity and Relationship Infidelity European." Journal of Personality 18: 301-319. 
Seem, Debbie L., Lee Ingi, Craig A. Umscheid, and Matthew J. Kuehnert. 2011. "PHS Guideline for Reducing Transmission of Human Immunodeficiency Virus (HIV), Hepatitis B (HBV), and Hepatitis C Virus (HCV) through Solid Organ Transplantation" Center for Disease Control.

Shilts, Randy. 1988. And the Band Played On: People, Politics, and the Aids Epidemic. New York, NY. St. Martin's Press.

Smith, Earl and Angela J. Hattery. 2006. "Hey Stud: Race, Sex, and Sports." Sexuality and Culture 10(2): 3-32.

Smith, Tom W. 1992. "Discrepencies Between Men and Women in Reporting Number of Sexual Partners: A Summary from Four Countries." Social Biology 39(3-4): $203-$ 211.

Spatz, Cathy and and Joseph B. Kuhns. 1996. "Childhood Victimization and Subsequent Risk for promiscuity, Prostitution, and Teenage Pregnancy:A Prospective." Study American Journal of Public Health 86(11): 1607-1612.

Tannahill, Reay. 1992. Sex in History. Chelsea, MI. Scarborough House Publishers.

Thomas, Keith. 1959. "The Double Standard." Journal of the History of Ideas 20: $195-$ 21.

University of Louisville. 2011. "School Profile" Retrieved on January 15, 2012 from http://louisville.edu/about/profile.html.

U. S. Census Bureau. 2010. American FactFinder fact sheet: Louisville-Jefferson County, KY-IN Metropolitan Statistical Area Retrieved February 15, 2012, from http://factfinder2.census.gov/faces/nav/jsf/pages/index.xhtml

Victor, Jeffrey S. 2004. "Sluts and Wiggers: A Study of the Effects of Derogatory Labeling Deviant Behaviork." Deviant Behavior 25: 67-85.

Vignetta, Charles E. and Robert W. Blum. 2008. "Core competencies and the prevention of high-risk sexual behavior." New Directions for Child and Adolescent Development: Core competencies to prevent problem behaviors and promote positive youth development, N. G. Guerra and C. P. Bradshaw (Eds.) 122: 61-74.

Weeks, Jeffrey. 1985. Sexuality and Its Discontents. Boston, MA. Routledge and Kegan Paul Plc.

Wheeler, Stanton. 1960. "Sex Offenses: A Sociological Critique." Law and Contemporary Problems 25(2): 258-278. 
Wiley, James A. and Stephen J. Herschkorn. 1988. "The Perils of Promiscuity." The Journal of Infectious Diseases 158(2): 500-501.

Winkler, Claudia. 2005. "Women and Conservatism after the Sexual Revolution." Society 42: $18-24$.

Workowski, Kimberly A. and Stewart Berman. 2010. "Sexually Transmitted Diseases Treatment Guidelines, 2010" Morbidity and Mortality Weekly Report 59(12): 1116. 


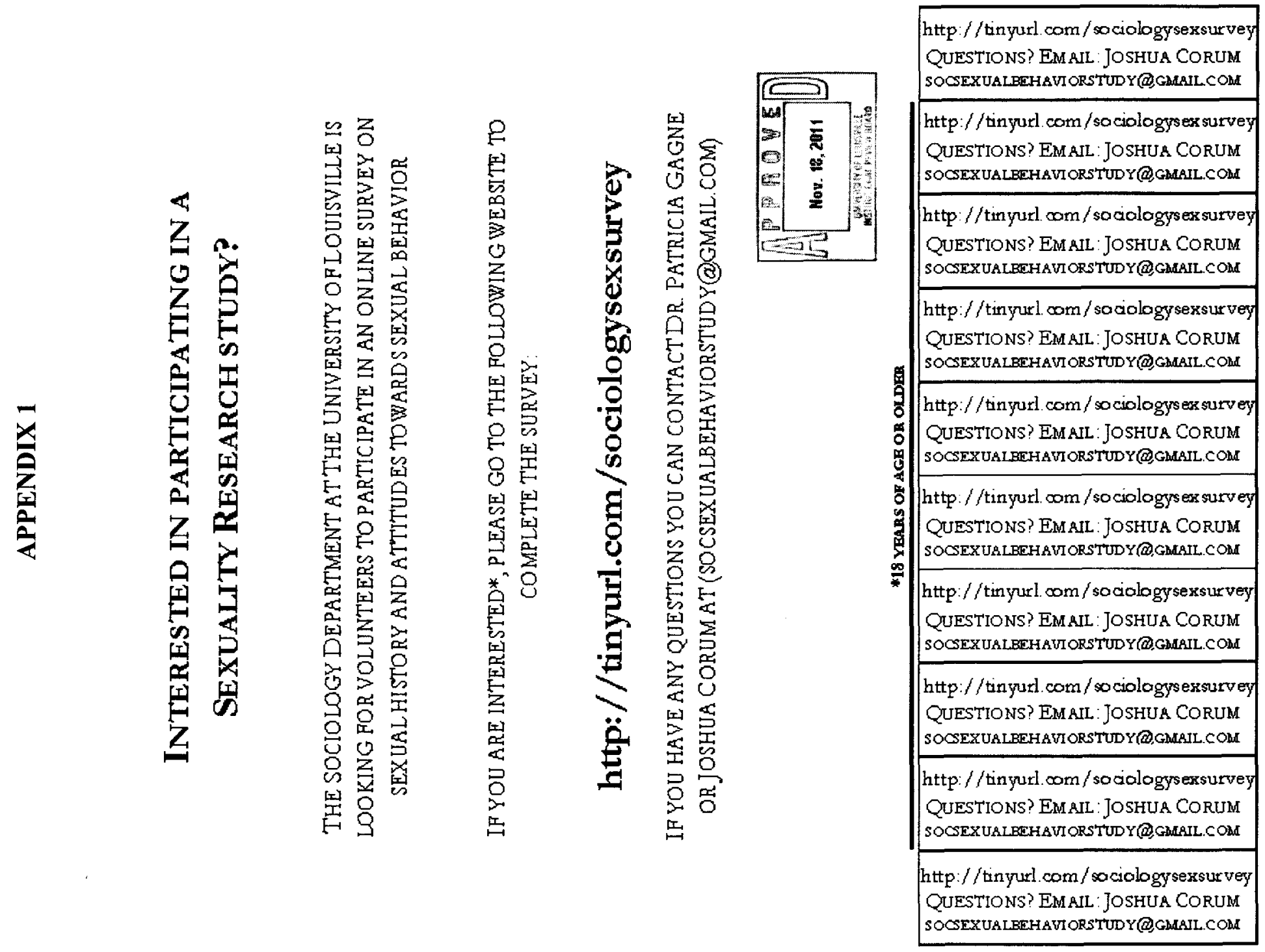




\begin{abstract}
APPENDIX 2
INTERESTED IN PAR TICIPATING IN A SEXUAUTY RESEARCH STUDY?

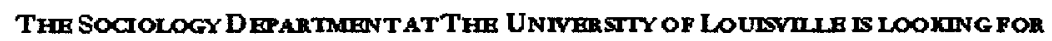
VOLUNT TEEES TO PARTICIPATE IN AN ONLINB SURVEY ON SEXXIAL FHSTOBY AND ATTTTUDES TOWARDS SEXULIL BEAAVIOR

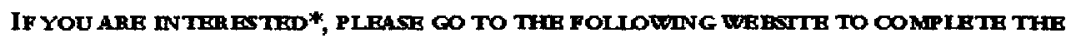
SURVEY:

\section{http://tinyurl.com/sociologysexsurvey}

If You have any ques mons you can contact Dr. Patilcta gagne or Joshula Cortumat (SOCSBXUAI_BFALAVIORSTUDY@GMAN_COM)

HE YEARS OF AGE OR OLDER

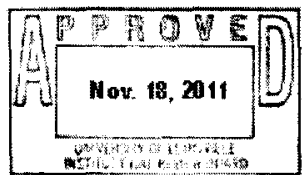




\begin{abstract}
APPENDIX 3
Study Participants Needed for online survey investigating Attitudes on Sexual Behavior

A sexual behavior study is being conducted through the Department of Sociology. This is an online survey investigating the sexual behavior and number of sexual partners of respondents and their opinions and views on the sexual behavior and number of sexual partners of others. We ask that you be 18 years of age or older to participate. Participation takes about 30-45 minutes and can be completed at home or other convenient place. Please go to the following link to begin the survey: http://tinyurl.com/sociologysexsurvey For more information, please call Joshua Corum or principle investigator, Patricia Gagne: socsexualbehaviorstudy@gmail.com IRB\# 11.0577
\end{abstract}




\section{APPENDIX 4}

\section{Promiscuity Survey}

1. What is your birth date? (MM/DD/YYYY)

2. What is your current City and State of residence? (ex. Louisville, KY)

3. Do you identify as: (please check one)
Male
$\square$ Female
$\square$ Transgender
$\square$ Intersexed
$\square$ Other

3a. If Transgender, are you: (please check one)
Male to Female
$\square$ Female to Male
$\square$ Cross-dresser
$\square$ Cross-dresser
$\square$ Other

4. Are you employed at a paid job?

$\square$ Yes - full-time

$\square$ Yes - part-time

$\square$ Yes, I am a temporary/seasonal worker

$\square$ No, I am unemployed or not working

$\square$ No, I am retired 
5. Please give the years of education completed: (Put "Don't Know" if unknown)

6. Did you earn a high school diploma or GED?

$\square$ Yes

$\square$ No

7. Did you attend college or university?

$\square$ Yes

$\square$ No

7a. If yes, what was your highest earned degree?

$\square$ A.A. or A.S.

$\square$ B.A. or B.S.

$\square$ M.A. or M.S.

$\square$ Ph.D. or MD

$\square$ No degree earned

$\square$ Don't Know

8. What is your religion?
$\square$ Protestant
Buddhist
$\square$ Catholic
$\square$ Hindu
$\square$ Jewish
$\square$ Other:
$\square$ Muslim
$\square$ None

9. Please, briefly describe your current religious or spiritual beliefs. 
10. How important is religion in your life?
o
$0 \quad 0$
o $\quad 0$
o
0
o
o $\quad 0$

1- Not Important

10 - Very Important

11. How would you describe your religious or spiritual upbringing?

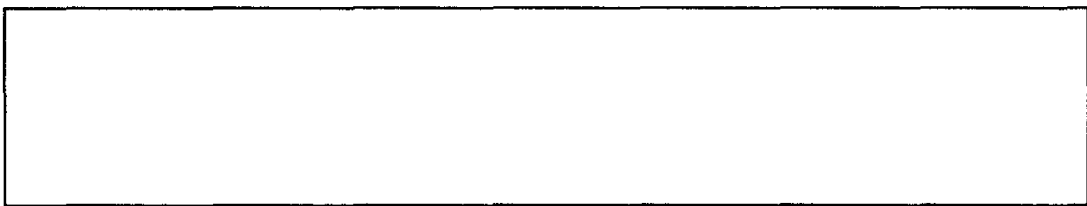

12. Are you:

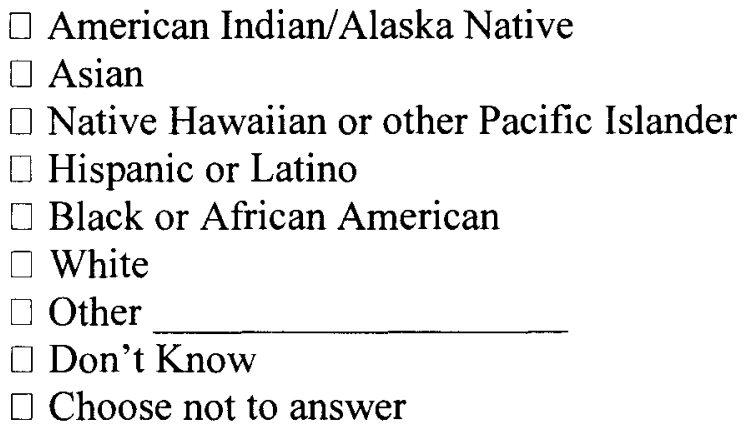

$\square$ Other

$\square$ Don't Know

$\square$ Choose not to answer

13. Which of the following best describes your current personal yearly income level?
$\square<\$ 10,000$
$\square \$ 10,000-\$ 19,999$
$\square \$ 20,000-\$ 29,999$
$\square \$ 30,000-\$ 39,999$
$\square \$ 40,000-\$ 49,999$
$\square \$ 50,000-\$ 59,999$
$\square \$ 60,000-\$ 69,999$
$\square \$ 70,000-\$ 79,000$
$\square \$ 80,000-\$ 89,999$
$\square \$ 90,000-\$ 99,999$
$\square>\$ 100,000$ 
14. What is your marital status?

Single/Never married

Cohabiting (Living together)

$\square$ Domestic Partnership

$\square$ Legally Married

Separated / Divorced

$\square$ Widowed

15. Which of these commonly used terms would you use to describe yourself?

$\square$ Heterosexual -- Straight

$\square$ Bisexual

$\square$ Homosexual -- Gay/Lesbian

$\square$ Queer/Pansexual

$\square$ Asexual

$\square$ Uncertain

$\square$ Other

16. Would you describe the type of person you find most sexually attractive as:

$\square$ Only female

$\square$ Mainly female but sometimes male

$\square$ Equally male or female

$\square$ Mainly male but sometimes female

$\square$ Only male

$\square$ Transgender - Male to Female

$\square$ Transgender - Female to Male

17. Do you consider yourself to be sexually active?

$\square$ Yes

$\square$ No

18. Would you describe your current sexual relationship as:

Committed and monogamous (that is, you have sex only with each other)

$\square$ Committed and non-monogamous/open (that is, one or both of you has sex with at least one other partner)

$\square$ No or undefined relationship but still sexually active with one partner

$\square$ No or undefined relationship but still sexually active with more than one partner

$\square$ Not in a sexual relationship 
18a. Is/Are your current sexual partner(s)?

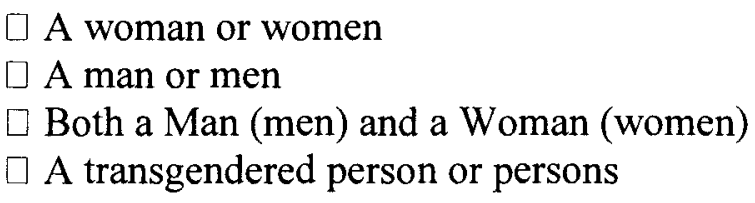

$18 \mathrm{~b}$. If you currently are in one or more sexual relationship(s), for how long have you been in this/these relationship?

$1^{\text {st }}$ or Primary relationship

years $\_$months
years
years
months
months

19. Have you ever been tested for an STI (Sexual Transmitted Infection)?

$\square$ Yes

$\square$ No

$\square$ Don't Know

19a.If yes, how frequently do you get tested?

$\square$ Only once in your life

$\square$ Once ever few years

$\square$ Once a year

$\square$ Twice a year

$\square$ Every 3-4 months

$\square$ Don't Know

19b. If yes, how recent was your last test?

week(s) ago month(s) ago year(s) ago

20. Did you receive sex education in elementary school?
$\square$ Yes
$\square$ No 
21. Did you receive sex education in high school?

$\square$ Yes

$\square$ No

21a. Was it abstinence only education?

Yes

$\square$ No

22. How old were you when you had your first sexual experience? (years old)

23. What sexual activities did you do? (Check all that apply)

$\square$ Kissing

$\square$ Heavy Petting

$\checkmark$ Outercourse (dry humping)

$\square$ Hand to Genital contact (Masturbation)

$\square$ Mouth to Genital contact (oral sex)

$\square$ Genital to Genital contact

$\square$ Vaginal Intercourse

$\square$ Anal Intercourse

$\square$ Other

24. At what age did you lose your virginity? (use " 0 " if still a virgin)

25. What sexual activity do you consider losing your virginity? (Check all that apply)

Kissing

$\square$ Heavy Petting

$\square$ Outercourse (dry humping)

$\square$ Giving Hand to Genital contact (Masturbation)

$\square$ Receiving Hand to Genital contact (Masturbation)

$\square$ Giving Mouth to Genital contact (oral sex)

$\square$ Receiving Mouth to Genital contact (oral sex)

$\square$ Genital to Genital contact

$\checkmark$ Vaginal Intercourse

$\square$ Anal Intercourse

$\square$ Other 
26. How many different partners have you had sex with in your lifetime? (If you are unsure, please estimate)

27. How many different partners have you had sex with on one and only one occasion in your lifetime? (If you are unsure, please estimate)

28. How many different partners have you had unprotected sexual intercourse with during the past three years? (If you are unsure, please estimate)

29. In your opinion, a WOMAN becomes sexually promiscuous when she has had sexual intercourse with number of partners?

30. Please give a brief explanation for the number you chose or if you were unable to provide a number.

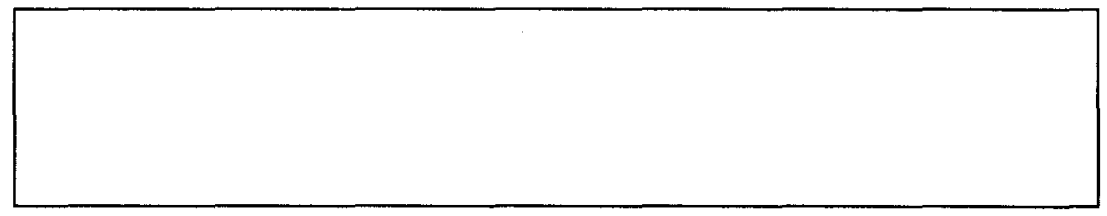

31. In your opinion, a MAN becomes sexually promiscuous when she has had sexual intercourse with number of partners?

32. Please give a brief explanation for the number you chose or if you were unable to provide a number. 
33. If a potential sexual partner had engaged in sex with other individuals before the two of you met, what number of sexual partners would start to make you feel uncomfortable? Number of Partners

34. What number of previous partners would make you not want to have sex with that potential partner?

Number of Partners

35. Please give a brief explanation for your answers to the previous two questions or if you were unable to provide answers.

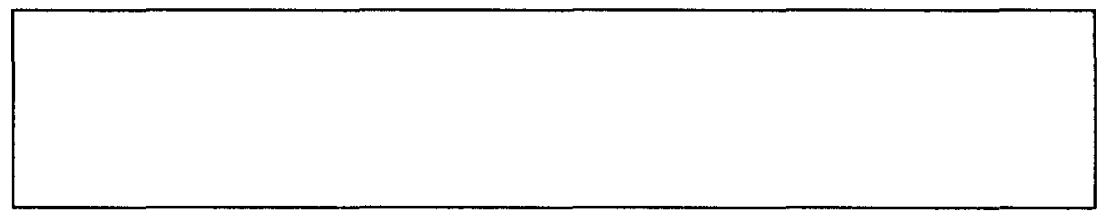

36. To what degree does an individual with a HIGH number of previous sexual partners affect your decision to have intercourse with them?
0
0
o
$0 \quad 0$
o
0
$0 \quad 0$

1- Not at all

$10-$ Very Much so

36a. Does a High number of previous sexual partners affect your decision:
Positively
Negatively
$\square$ Don’t Know

37. If a potential sexual partner had engaged in sexual intercourse with other individuals before the two of you met, what number of sexual partners would you consider being TOO FEW?

\section{Number of Partners}

38. Does an individual with a LOW number of previous sexual partners affect your decision to have intercourse with them?

o
o
o
0
0
o
0
$0 \quad 0$

1- Not at all

10 - Very Much so 
38a. Does a LOW number of previous sexual partners affect your decision:

$\square$ Positively

$\square$ Negatively

$\square$ Don't Know

39. Do you prefer a sexual partner to be a virgin?

$\square$ Yes

$\square$ No

$\square$ Don't Know

40. Do you typically ask about a partner's sexual history, BEFORE engaging in sexual activity?

$\square$ Yes

$\square$ Sometimes

$\square$ No

41. Do you typically ask about a partner's sexual history, AFTER engaging in sexual activity?

$\square$ Yes

$\square$ Sometimes

$\square$ No

42. Have you ever Over-reported or Under-reported your number of previous sexual partners to friends?

$\square$ Yes - Over-reported

$\square$ Yes - Under-reported

$\square$ No

$\square$ Don't Know 
43. Have you ever Over-reported or Under-reported your number of previous sexual partners to a Boyfriend/Girlfriend or Spouse?

$\square$ Yes - Over-reported

$\square$ Yes - Under-reported

$\square$ No

$\square$ Don't Know

For the following questions if you are not single or sexually active, please imagine that you are single and sexually active and answer to the best of your ability.

44. If you were looking for a short term casual sexual relationship would you prefer a person who had than you?

$\square$ Substantially more partners

$\square$ Slightly more partners

$\square$ About the same number of partners

$\square$ Slightly fewer partners

$\square$ Substantially fewer partners

$\square$ Don't care

$\square$ I would not have a casual sexual relationship

45. If you were to enter into a short term casual sexual relationship with someone, how many previous sexual partners would you consider too many for them to have had?

Number of Partners

46. If you were to enter into a short term casual sexual relationship with someone, how many previous sexual partners would you consider too few for them to have had?

Number of Partners

[.] No minimum number 
47. If you were looking for a Long term committed relationship would you prefer a person who had_than you?

Substantially more partners

$\square$ Slightly more partners

About the same number of partners

Slightly fewer partners

Substantially fewer partners

Don't care

$\square$ I would not have a casual sexual relationship

48. If you were to enter into a long term committed with someone, how many previous sexual partners would you consider too many for them to have had?

Number of Partners

49. If you were to enter into a long term committed relationship with someone, how many previous sexual partners would you consider too few for them to have had?

Number of Partners

$\sqsubset$ No minimum number

50. If you were looking to marry would you prefer a person who had than you?

$\square$ Substantially more partners

$\square$ Slightly more partners

$\square$ About the same number of partners

$\square$ Slightly fewer partners

$\square$ Substantially fewer partners

$\square$ Don't care

$\square$ I would not have a casual sexual relationship

51. If you were to marry someone, how many previous sexual partners would you consider too many for them have had?

Number of Partners 
52. If you were to marry someone, how many previous sexual partners would you consider too few for them have had?

Number of Partners

$\square$ No minimum number

There are many considerations one makes when choosing a sexual partner. If you knew a potential partner had a HIGH number of previous sexual partners, please rate how important the following concerns are to you in making your decision to have sex with that person.

53. Your Physical Health (STI's, emotional attachments, etc.)

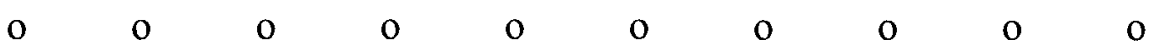

1- Not at all

10 - Extremely

Important Important

54. Your Mental Health (STI's, emotional attachments, etc.)
o
0
0
o
o
o
o

o
o $\quad 0$

1 - Not at all

10 - Extremely

Important

Important

55. The Potential Partner's Physical Health (STI's, emotional difficulties, eyc.)
o
o
o
o
o
o
o
$0 \quad 0 \quad 0$

1- Not at all

10 - Extremely

Important

Important

56. The Potential Partner's Mental Health (STI's, emotional difficulties, eyc.)

$\begin{array}{llllllllll}0 & 0 & 0 & 0 & 0 & 0 & 0 & 0 & 0 & 0\end{array}$

$1-$ Not at all

10 - Extremely

Important

Important 
57. Religious/Moral Reasons

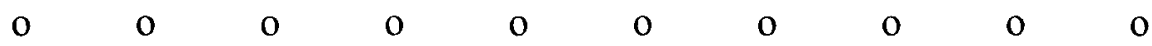

1- Not at all

10 - Extremely

Important

Important

59. Sexual Significance (wanting to feel sexual important to your partner)
$0 \quad 0$
o
O
O
0
O
$0 \quad 0$

1 - Not at all

10 - Extremely

Important Important

60. Experience (fear that you may be less experienced than your partner)
o
O
O
O
$\mathrm{O}$
o $\quad 0$
O
o $\quad 0$

1 - Not at all

10 - Extremely

Important

Important

61. In your own words, please give a brief explanation for your top 3 concerns from the previous question. 


\section{Premarital Sex Permissiveness Scale}

For each of the following statements, indicate to what extent you agree or disagree with it. These statements concern what you think is appropriate behavior for you.

62. I believe that sexual intercourse is acceptable for me on a first date.

$\square$ Agree Strongly

$\square$ Agree Moderately

$\square$ Agree Slightly

$\square$ Disagree Slightly

Disagree Moderately

$\square$ Disagree Strongly

63. I believe that sexual intercourse is acceptable for me when I'm casually dating my partner (dating less than one month).

$\square$ Agree Strongly

$\square$ Agree Moderately

$\square$ Agree Slightly

$\square$ Disagree Slightly

$\square$ Disagree Moderately

$\square$ Disagree Strongly

64. I believe that sexual intercourse is acceptable for me when I'm seriously dating my partner (dating almost a year).

Agree Strongly

$\square$ Agree Moderately

Agree Slightly

Disagree Slightly

$\square$ Disagree Moderately

$\square$ Disagree Strongly 
65. I believe that sexual intercourse is acceptable for me when I am pre-engaged to my partner (we have seriously discussed the possibility of getting married).
Agree Strongly
Agree Moderately
Agree Slightly
Disagree Slightly
Disagree Moderately
$\square$ Disagree Strongly

66. I believe that sexual intercourse is acceptable for when I'm engaged to my partner.
Agree Strongly
$\square$ Agree Moderately
$\square$ Agree Slightly
$\square$ Disagree Slightly
○ Disagree Moderately
$\square$ Disagree Strongly

\section{Sexual Double Standard Scale}

Please indicate your response to the following questions about your attitudes about the sex roles of men and women. Please keep in mind that there are no wrong answers. Please answer honestly.

67. It is expected that a woman be less sexually experienced than her partner.

$\square$ Strongly agree

Agree

Undecided

Disagree

$\square$ Strongly disagree

68. A woman who is sexually active is less likely to be considered a desirable partner.

$\square$ Strongly agree

$\square$ Agree

$\square$ Undecided

$\square$ Disagree

$\square$ Strongly disagree 
69. A woman should never appear to be prepared for a sexual encounter.

$\square$ Strongly agree

$\square$ Agree

$\square$ Undecided

$\square$ Disagree

$\square$ Strongly disagree

70. It is important that the man be sexually experienced so as to teach the woman.

Strongly agree

Agree

Undecided

Disagree

$\square$ Strongly disagree

71. A "good" woman would never have a one-night stand, but it is expected of a man.

Strongly agree

Agree

Undecided

$\square$ Disagree

$\square$ Strongly disagree

72. It's important for a man to have multiple sexual experiences in order to gain experience.

Strongly agree

$\square$ Agree

$\square$ Undecided

$\square$ Disagree

$\square$ Strongly disagree

73. In sex the man should take the dominant role and the woman should take the passive role.

$\square$ Strongly agree

$\square$ Agree

$\square$ Undecided

$\square$ Disagree

$\square$ Strongly disagree 
74. It is acceptable for a woman to carry condoms.

$\square$ Strongly agree

$\square$ Agree

$\square$ Undecided

$\square$ Disagree

$\square$ Strongly disagree

75. It is worse for a woman to sleep around than it is for a man.

$\square$ Strongly agree

$\square$ Agree

$\square$ Undecided

$\square$ Disagree

$\square$ Strongly disagree

76. It is up to the man to initiate sex.

$\square$ Strongly agree

$\square$ Agree

$\square$ Undecided

$\square$ Disagree

$\square$ Strongly disagree

77. The sexual double standard is the idea that it is more socially acceptable for men than women to be sexually experience and have several sexual partners in their lifetime.

Women are expected to be sexually reserved and have few to no sexual partners outside of marriage. Do you believe this double standard still holds true today? Can you give an example in your life to build upon your answer?

78. How would you personally define promiscuity? 
79. When you were growing up, what were you told or what messages did you receive about acceptable sexual behavior for men and women from places such as Parents? Peers? Media? Religion (if applicable)? School? or Other sources?

80. In the box below, please write any comment or suggestions you may have about the questionnaire you just completed? 


\section{APPENDIX 5}

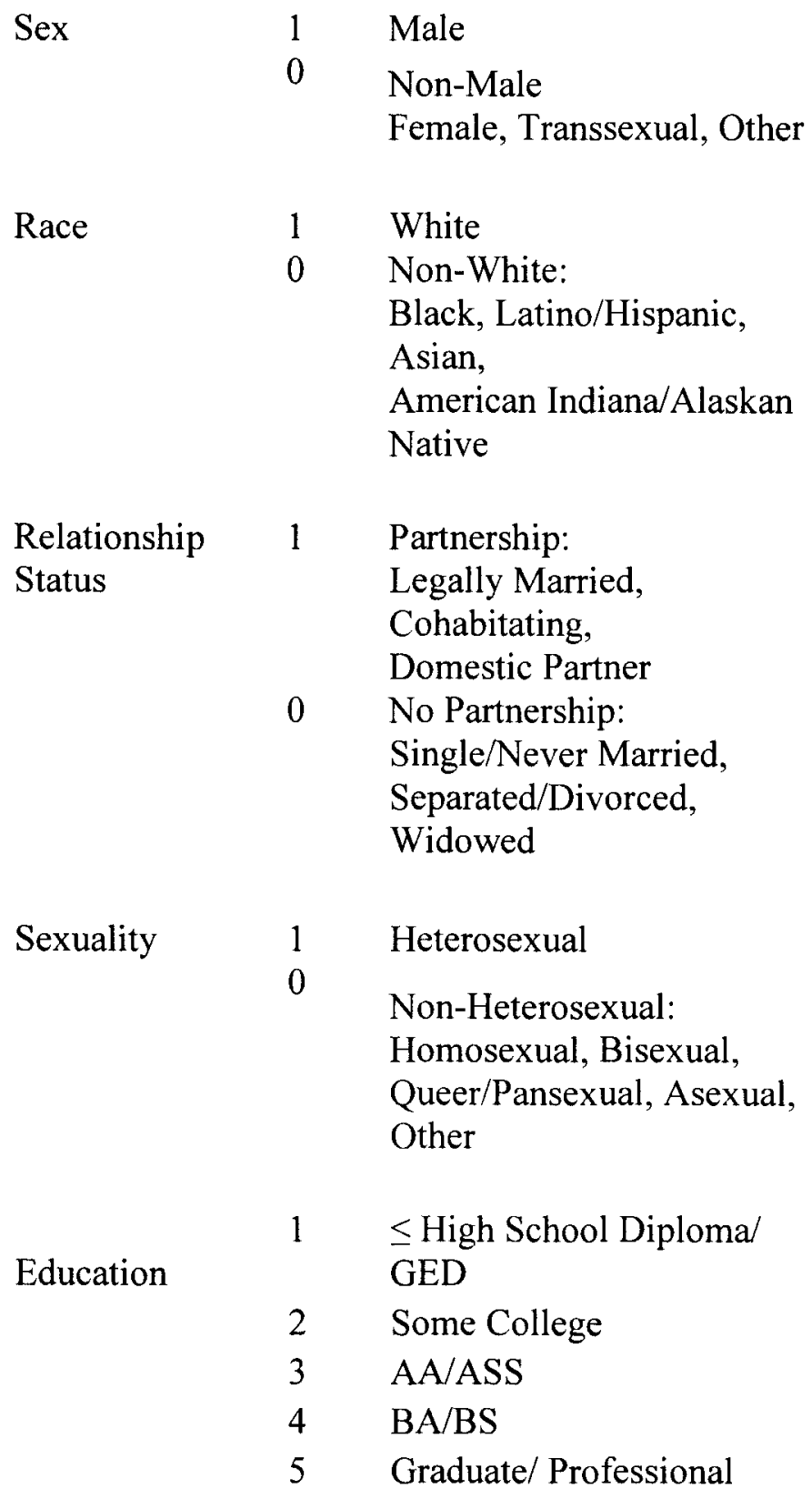




\title{
CURRICULUM VITAE
}

\author{
Joshua O. Corum
}

Department of Sociology

University of Louisville

Louisville, Kentucky 40292

joshua.corum@louisville.edu

\section{EDUCATION}

University of Louisville

Louisville, KY

Master of the Arts: Sociology

Currently

Thesis: "“What do you mean I'm a slut?!?!" Deconstructing the Definitions of

Promiscuity of the Collective Conscience using Concepts from Labeling Theory and Biopower

\section{Indiana University}

Majors: Psychology and Human Sexuality

Bloomington, IN

Minor: Sociology

May 2007

SUNY Tompkins-Cortland Community College

Concentration: Psychology

\author{
Dryden, NY \\ January 2003 - May 2004
}

\section{TEACHING EXPERIENCE}

Soc 201 - Introduction to Sociology (Recitation)

Graduate Teaching Assistant

University of Louisville

Responsibilities include:

- Writing and presenting lectures

- Constructing and grading assignments, quizzes, and exams

Soc 201 - Introduction to Sociology (Online)

University of Louisville

Graduate Teaching Assistant

Fall 2011 - Spring 2012

Responsibilities include:

- Technical facilitation

- $\quad$ Writing and presenting lectures 
Project: Gender Differences in the Effects of Sexual Arousal on Attention and Perception

Research Assistant March 2005 - May 2005

- $\quad$ Ran experimental sessions using the MediaLab software package

- $\quad$ Facilitated post-experimental interviews

\section{RESEARCH INTERESTS}

Conflict Theory and Commodification

Polyamory and Alternative relationship Styles

Promiscuity and Personal Sexual Histories

\section{TEACHING INTERESTS}

Human Sexuality

Social theory

Intro-Sociology

\section{PRESENTATIONS}

Corum, J \& P. Gagné. "Quantifying Promiscuity: Assessing Individual Attitudes on Sexual Behavior" Student Poster at the Society for the Scientific Study of Sex (SSSS)

Annual Meeting 2011. Houston, TX

Corum, J. \& E. Janssen. "The Sexual double Standard Revisited: Men and Women's Attitudes toward a Potential Partner's Previous Sexual History." Presented at the Annual Meetings of the Anthropologists and Sociologist of Kentucky, Columbia, KY. October 2010. Revised manuscript revised to be submitted for journal review Spring 2012.

\section{HONORS AND AWARDS}

2012 Graduate Dean's Citation

University of Louisville

\section{Outstanding Student Ambassador Award}

Society for the Scientific Study of Sex (SSSS) Annual Meeting 2011

2010 Jules Delambre Student Paper contest $-1^{\text {st }}$ Place Undergraduate Paper

Annual Meeting of Anthropologist and Sociologist of Kentucky, 2010

"The Sexual double Standard Revisited: Men and Women's Attitudes toward a Potential

Partner's Previous Sexual History"

\section{Most Outstanding Senior Project Award}

Individualized Major Program, Indiana University.

"The Sexual double Standard Revisited: Men and Women's Attitudes toward a Potential

Partner's Previous Sexual History."

\section{PROFESSIONAL ASSOCIATIONS}

Society for the Scientific Study of Sex (SSSS) - Student Ambassador

Sociology Graduate Student Association (University of Louisville)

\section{EMPLOYMENT}

\section{University of Louisville}

Louisville, KY Graduate Teaching Assistant January 2011 - Present 